\title{
A comparison of buy-side and sell-side analysts
}

\author{
Jeffrey Hobbs ${ }^{\mathrm{a}, 1}$, Vivek Singh ${ }^{\mathrm{b}, *}$ \\ ${ }^{a}$ Department of Finance, Banking and Insurance, Walker College of Business, Appalachian State University, United States \\ ${ }^{\mathrm{b}}$ Department of Accounting and Finance, University of Michigan, Dearborn, United States
}

\section{A R T I C L E I N F O}

\section{Article history:}

Received 5 June 2014

Received in revised form 9 December 2014

Accepted 31 December 2014

Available online 31 January 2015

\section{JEL classification:}

G11

G14

G20

G23

Keywords:

Sell-side analysts

Buy-side analysts

Institutional investors

Analyst recommendations

Market efficiency

\begin{abstract}
A B S T R A C T
There is very little research on the topic of buy-side analyst performance, and that which does exist yields mixed results. We use a large sample from both the buy-side and the sell-side and report several new results. First, while the contemporaneous returns to portfolios based on sell-side recommendations are positive, the returns for buyside analysts, proxied by changes in institutional holdings, are negative. Second, the buy-side analysts' underperformance is accentuated when they trade against sell-side analysts' recommendations. Third, abnormal returns positively relate to both the portfolio size and the portfolio turnover of buy-side analysts' institutions, suggesting that large institutions employ superior analysts and that superior analysts frequently change their recommendations. Abnormal returns are also positively related to buy-side portfolios with stocks that have higher analyst coverage, greater institutional holding, and lower earnings forecast dispersion. Fourth, there is substantial persistence in buy-side performance, but even the top decile performs poorly. These findings suggest that sell-side analysts still outperform buy-side analysts despite the severe conflicts of interest documented in the literature.
\end{abstract}

Crown Copyright (c) 2015 Published by Elsevier Inc. All rights reserved.

\section{Introduction}

There is much research on the profitability of sell-side analysts' recommendations. By contrast, there are only a few papers that investigate the performance of buy-side analysts' recommendations. Some of the more recent papers in this area have examined buy-side performance in the context of sell-side behavior, but most use a limited sample, suffer from survivorship bias, or do not fully examine the link between the buy and sell sides to quantify the part of institutions' profit or loss that is incremental to analyst recommendations. In the following study, we fill in this gap by examining a large sample of survivorship-bias-free data from both sides of the market to measure the profitability of buy-side analysts in four ways: (1) overall, (2) cross-sectionally, (3) temporally (in terms of both absolute and relative persistence), and (4) with respect to changes in sell-side analyst recommendations, to determine the relative value of the two sides' behavior.

How do institutions decide which securities to buy and which to sell? The final say goes to the fund manager, but fund managers (as well as the investment committees that make trading recommendations to

\footnotetext{
* Corresponding author. Tel.: +1 313583 6533; fax: +1 3132719837.

E-mail addresses: hobbsjc@appstate.edu (J. Hobbs), vatsmala@umich.edu (V. Singh).

1 Tel.: +1 828262 6241; fax: + 18282626612 .
}

their firms) are known to rely heavily on their analysts. ${ }^{2}$ It is under the assumption that buy-side trading is influenced largely by buy-side analyst recommendations that we use institutional portfolio data as our proxy for buy-side analyst behavior. To the extent that institutional investors have access to recommendations from sell-side analysts, one could argue that our proxy is a dirty measure of buy-side analyst recommendations. We agree with this argument and we address this concern by concentrating on the buy-side analysts' induced institutional trades that explicitly go against the recommendations of sell-side analysts for much of our analysis. Additionally, by using the Thomson 13F dataset, we restrict ourselves to using quarterly observations, whereas some studies using proprietary data (see Frey \& Herbst, 2014 or Crawford, Gray, Johnson, \& Price, 2012, both of which employ daily data) have access to more detailed information on trading behavior, though for limited time periods. While we acknowledge that the main disadvantages of our dataset and sample construction are not eliminated, we also have the advantage of more comprehensively comparing sell-side and buyside analysts over a long period in a way that contains less selectionor survivorship-bias than is present in much of the recent literature.

Although some evidence shows that institutional investors in general and mutual funds in particular, and by extension the buy-side analysts that they employ, do not generate positive abnormal returns

\footnotetext{
${ }^{2}$ Analysts are usually members of the investment committees.
} 
and thus could be considered non-helpful (or downright harmful, depending on the study) to investors, ${ }^{3}$ there is considerable evidence that sell-side analysis is beneficial. Among others, Logue and Tuttle (1973), Dimson and Marsh (1984), Elton, Gruber, and Grossman (1986), Womack (1996), Barber, Lehavy, McNichols, and Trueman (2001, 2003), and Jegadeesh, Kim, Krische, and Lee (2004) find changes in analysts' recommendations to be consistent with subsequent abnormal stock returns. Jegadeesh and Kim (2006) find that analyst recommendations are profitable, particularly for those analysts based in the U.S., while Howe, Unlu, and Yan (2009) find recommendations to contain profitable information extending beyond other variables that are related to future returns. Despite the evidence in support of sellside analysts, there are also papers that document some problems, usually stemming from optimism bias or conflicts of interest, with analyst recommendations. Both Lin and McNichols (1998) and Michaely and Womack (1999) document such conflicts; for example, the latter study finds that underwriter analysts exhibit significant optimism bias for those stocks that they've underwritten. Malmendier and Shanthikumar (2014) find that strategic optimism bias (the bias created by conflicts of interest) appears to be intentional, widespread, and economically substantial. Conrad, Cornell, Landsman, and Rountree (2006) find that optimism bias is also related to past events and is reflected in the asymmetric response of analysts to the directions of large stock price moves in the past. Jegadeesh et al. (2004) find that analyst recommendation levels relate positively to future returns only for those stocks with upward momentum or contrarian characteristics. Additionally, the authors find that analyst recommendation levels relate inversely to future returns for other stocks in their dataset. Last, Altinkilic and Hansen (2009) and Altinkilic, Balashov, and Hansen (2013) find that revisions to analyst recommendations are typically reactive rather than predictive and thus are of little trading value to investors.

In addition to the evidence regarding aggregate performance, there are also well-documented cross-sectional differences between stock analysts. Analyst performance has been tied to the accuracy of earnings forecasts (Ertimur, Sunder, \& Sunder, 2007 and Loh \& Mian, 2006), past performance (Fang \& Yasuda, 2009 and Loh \& Stulz, 2011), the frequency of recommendation revisions (Hobbs, Kovacs, \& Sharma, 2012), and incentive distortions caused by investment banking affiliations (Barber, Lehavy, \& Trueman, 2007).

Many recent studies have compared buy-side profitability to sellside recommendations to obtain a clearer picture of the overall process of institutional trading. Although much of this research uses proprietary data from other parts of the buy-side previously ignored by the mutual fund studies, they often use limited datasets and yield differing results. Cheng, Liu, and Qian (2006) find that funds rely more on buy-side research than on sell-side or independent research, and that abnormal returns increase in buy-side reliance and experience. These funds also value buy-side research more when the sell-side focuses on small stocks or has larger forecast errors and forecast dispersion. Kacperczyk and Seru (2007) report that the funds that have more skilled managers tend to prefer private (buy-side) information to public (sell-side)

\footnotetext{
${ }^{3}$ The research on the investment performance of institutions (the "buy-side") dates back to Jensen (1968) and continues through well-known studies by Lakonishok, Shleifer, and Vishny (1992), Carhart (1997), Fama and French (2008), and Busse et al. (2010), among others. There is some debate over how much of the persistence in performance (good or bad) is attributable to the momentum effect of stocks remaining in their respective mutual funds after those funds have been designated winners or losers on the basis of the past performance of those same stocks. Carhart (1997), Barras, Scaillet, and Wermers (2009), and Fama and French (2008) show very little (if any) persistence or predictability in the performance of mutual funds that is incremental to the momentum effect of the stocks in them. However, Berk and Xu (2007), Bollen and Busse (2005), Cohen, Coval, and Pastor (2005), Avramov and Wermers (2006), and Kosowski, Timmermann, Wermers, and White (2006) all find evidence that mutual fund performance is to some degree predictable. Binay (2005) uses Thomson 13F holdings data and finds that while mutual funds do not trade profitably, other institutional investors do. Chen et al. (2000), however, use $13 \mathrm{~F}$ quarterly holdings data to find some evidence of mutual fund trading success.
}

information. Similarly, Frey and Herbst (2014), using a sample from one firm, find that fund trading is driven more by buy-side recommendations than by sell-side recommendations or fund flows, and that those trades that are triggered by buy-side recommendations yield the highest excess returns. Last, Crawford et al. (2012) use data from an invitation-only, Facebook-style event and conclude that buy-side recommendations do have investment value, particularly for firms with small capitalizations and high book-to-market ratios.

In contrast, Groysberg, Healy, Serafeim, Shanthikumar, and Gui (2010) compare buy-siders at one large firm to sell-siders on $\mathrm{I} / \mathrm{B} / \mathrm{E} / \mathrm{S}$ and conclude that buy-side recommendations are less optimistic, owing to fewer conflicts of interest, and interestingly are less profitable. However, the authors attribute this lower profitability to the fact that buy-siders recommend larger firms, on average, than do sell-siders. Similarly, Busse, Green, and Jegadeesh (2012) examine a more comprehensive sample of buy- and sell-side activities and find that sell-side analyst recommendations are profitable while buy-side activity is largely alpha-neutral. The authors conclude that institutional trading offers no incremental value to sell-side stock recommendations. There are at least two shortcomings of the papers that rely on limited samples. First, the data are often provided by the institutions themselves and, as Busse et al. (2012) point out, survivorship bias plagues much of the buy-side research. Second, although some of these studies report that buy-side analysts generate superior recommendations, much of the research finds that the typical institution that hires buy-side analysts does not generate positive abnormal returns. This paper addresses these issues. In particular, we attempt to provide a more comprehensive understanding of the link between buy-side and sell-side analysts along three dimensions. First, we examine the nature of buy-side induced institutional trading and sell-side analyst recommendations individually with respect to the same-quarter movements of those stocks. Second, we examine the behavior of the two sides with respect to one another in the context of the stocks that they trade or recommend. Third, we examine the persistence of performance among buy-side analysts. We believe that our approach offers new evidence, from a more comprehensive dataset including different types of institutions as well as analyst recommendations, on all of these important topics.

The rest of our paper is structured as follows. Section 2 describes the data and methods that we use. Section 3 addresses the topic of buy- and sell-side behaviors individually and with respect to one another. Section 4 investigates the issue of persistence. Section 5 concludes the study.

\section{Material and methods}

\subsection{Sample data}

Our institutional ("buy-side") data come from the Thomson Financial 13-F filings. These filings include information on the quarterly stock holdings, beginning in the first quarter of 1994, of all financial institutions that manage more than $\$ 100$ million in securities. ${ }^{4}$ Although only equity positions of more than either 10,000 shares or $\$ 200,000$ in market capitalization are required to be reported, many institutions voluntarily provide data on all of their holdings. We then examine the changes in these buy-side investment portfolios over 64 quarters, from the first quarter of 1994 through the fourth quarter of 2009. We use the Institutional Brokers' Estimates System (hereafter denoted "IBES") to gather our analyst recommendation ("sell-side") data over the same period. We match the 8-character CUSIP variable in the detailed recommendation file in IBES to that in the Center for Research in Security Prices ("CRSP", hereafter) database and then use the 6-character CUSIP if

\footnotetext{
4 The start of the data period is dictated by the IBES detailed recommendation files (required to infer buy-side recommendations), whose first complete year of data begins in 1994.
} 
that fails to produce a match. Our sample excludes ADRs (American Depositary Receipts), SBI (Shares of Beneficial Interest), Units (Depository Units, Units of Beneficial Interest, Units of Limited Partnership Interest, Depository Receipts, etc.), REITs (Real Estate Investment Trusts), and closed-end mutual funds. For both the buy-side and the sell-side, we do not censor or winsorize any of the variables in our dataset.

\subsection{Classifying buy-side behavior}

For each quarter, we infer buy-side analyst activity by observing the information-based trading done by the institution that employs the analyst. Specifically, if a stock is bought (sold) by the institution, we assume that the affiliated buy-side analyst(s) must have upgraded (downgraded) that stock in the same quarter. The exact procedure to identify stocks that are upgraded (downgraded) by the analysts is outlined as follows. First we identify for each institutional investor whether each stock is bought (sold) in a quarter by measuring the change in its holding in the same quarter. Since institutional investors do not buy or sell a stock due to informational reasons only, we employ several adjustments to ensure that our identification of trades is not contaminated by other motives for institutional trading. The first adjustments control for the return on the existing holding of stock $i$ and the net flow of funds to the institutional investor during the current quarter, t. For each quarter, we use the following formula, which was inspired by Barber, Odean, and Zhang (2005), and Griffin, Harris, Shu, and Topaloglu (2011), to determine whether for each stock $i$ in quarter $\mathrm{t}$ an institutional investor $\mathrm{K}$ is a buyer (Inst( $\mathrm{i}, \mathrm{t})$ is positive) or a seller (Inst(i,t) is negative).

$$
\operatorname{Inst}(\mathrm{i}, \mathrm{t})=\frac{\mathrm{S}_{\mathrm{i}, \mathrm{t}} \mathrm{P}_{\mathrm{i}, \mathrm{t}}-\mathrm{S}_{\mathrm{i}, \mathrm{t}-1} \mathrm{P}_{\mathrm{i}, \mathrm{t}-1}(1+\mathrm{r})}{\mathrm{S}_{\mathrm{i}, \mathrm{t}-1} \mathrm{P}_{\mathrm{i}, \mathrm{t}-1}}-\frac{\sum_{\mathrm{i}=1}^{\mathrm{N}=\mathrm{m}} \mathrm{S}_{\mathrm{i}, \mathrm{t}} \mathrm{P}_{\mathrm{i}, \mathrm{t}}-\sum_{\mathrm{i}=1}^{\mathrm{N}=\mathrm{m}} \mathrm{S}_{\mathrm{i}, \mathrm{t}} \mathrm{P}_{\mathrm{i}, \mathrm{t}-1}(1+\mathrm{r})}{\sum_{\mathrm{i}=1}^{\mathrm{N}=\mathrm{m}} \mathrm{S}_{\mathrm{i}, \mathrm{t}-1} \mathrm{P}_{\mathrm{i}, \mathrm{t}-1}}
$$

An institution $\mathrm{K}$ that is a net buyer (seller) of stock i in quarter $\mathrm{t}$ will yield a positive (negative) value for the above expression. In other words a positive (negative) value is consistent with buy-side analysts upgrading (downgrading) the stock in the same quarter. $S_{\mathrm{i}, \mathrm{t}}$ and $\mathrm{S}_{\mathrm{i}, \mathrm{t}-1}$ are the number of shares held by institutional investor $\mathrm{K}$ in stock $\mathrm{i}$ at the end of quarters $t$ and $t-1$ respectively. $P_{i, t}$ and $P_{i, t-1}$ are the share price of stock $i$ at the end of quarters $t$ and $t-1$, respectively. The return on stock $i$ in the current quarter $t$ is captured by $r$. Thus the first term in the expression in (2) represents net buying or selling in stock i in quarter $t$ by institutional investor $K$ as a fraction of its initial holding of the stock, adjusted for the return on stock $i$ in the current quarter. The second term represents the net buying or selling by the same institution across all stocks traded in quarter $\mathrm{t}$. If institutional investor $\mathrm{K}$ faces an inflow (outflow) of funds in quarter $t$, we expect the second term to be positive (negative). Therefore this expression measures, for each stock in each quarter, the buying or selling that is in excess of the net flow of funds to institutional investor $\mathrm{K}$. We also adjust the share holdings and prices for outside factors that affect the number of shares, such as stock splits and stock dividends.

Further, we construct the following filters to ensure that our results based on Inst(i,t) are unaffected by trades that occurred for noninformation-based reasons. For example, as a new stock comes to the market via an initial public offering in a given quarter, most institutional investors will be net buyers. To correct for this problem, we consider Inst $(\mathrm{i}, \mathrm{t})$ for only those stocks that had also existed in the previous quarter, $t-1$. For similar reasons, we exclude Inst $(i, t)$ for those cases in which a stock ceases to exist because of a merger, acquisition, delisting etc.

Similar to IPOs, seasoned equity offerings may also affect Inst(i,t). We assume that if the number of shares outstanding (adjusted for stock splits, stock dividends, etc.) for a stock has increased by more than $25 \%$ from the previous quarter, then the firm has had a potential seasoned equity offering in the current quarter. ${ }^{5}$ We remove such stock-quarters from our final sample.

Because the performance of many institutions is benchmarked against stock market indexes, part of the institutional trading in stocks may be explained by indexing. To remove the potentially confounding effect of indexing on our results, we eliminate all Inst(i,t) that are affected by additions and deletions to the S\&P 500 index during the sample period. In order to do this we download a file containing all additions and deletions to the S\&P 500 index from Professor Jeffrey Wurgler's website. This file contains each stock's company identifier, addition or deletion flag, and the announcement date and effective date for its addition to (or deletion from) the index, among other variables. If the institutional trading in a stock is related to that stock's addition to (or deletion from) the S\&P 500 index, we expect most of the trading to occur around the quarter of the addition/deletion. We determine the quarter and year of the addition or deletion for all stocks in this sample using the effective date and then merge it with our sample of stocks. We exclude from our sample all stock-quarters in which additions or deletions occurred.

We acknowledge that although we make attempts to identify information-driven trades only and use the above-mentioned filters, we may be misclassifying some trades that are driven by other motives such as managerial risk shifting due to differential performance across parts of the year because of compensation incentives, employment risk motives or economic activity (Chevalier \& Ellison, 1997; Brown, Harlow, \& Starks, 1996; Chevalier \& Ellison, 1999; Kempf, Ruenzi, and Thiele, 2009; Pagani, Hu, Kale, and Subramanian, 2011; Olivier and Tay, 2009). Similarly some trading could be attributed to herding (Grinblatt, Titman, \& Wermers, 1995; Nofsinger \& Sias, 1999; Wermers, 1999). Some trading may also be related to Window dressing and tax-loss selling (Sias, 2007).

\subsection{Classifying sell-side analyst behavior}

To determine whether a stock was upgraded or downgraded by sell-side analysts in a quarter, we measure the change in the consensus recommendation at the end of each quarter using the IBES detailed analyst recommendation files. To compute the consensus recommendation for a stock, we use all outstanding recommendations by all analysts that are less than one year old, per Jegadeesh et al. (2004). We focus on upgrades and downgrades rather than on overall levels since the change in recommendations has been found to be more informative than the level of those recommendations (Jegadeesh et al., 2004). Additionally, prior research shows that analysts issue optimistic recommendations in the year that a stock first comes to the market. To mitigate the influence of this bias in analyst recommendations, we remove any recommendation that is issued within one year from the date that a firm went public.

\subsection{Methods}

Our examination of buy-side analysts is based on their institutions' portfolios of stocks, whose abnormal returns we derive by estimating time-series regressions of the contemporaneous and subsequent quarter's excess return as benchmarked against the CAPM, Fama and French (1993) three-factor model, and Carhart (1997) four-factor model. For sell-side analysts, we simply examine the abnormal performance of portfolios of stocks upgraded or downgraded as implied by the change in those analysts' recommendations. We use aggregate performance rather than a typical sell-side analyst's performance because there is much research indicating that the typical sell-side analyst generates positive alpha. However, the issue of aggregate buy-side analyst performance is far from settled. In addition, it could be argued that the

\footnotetext{
${ }^{5}$ We also use a more liberal $10 \%$ increase to proxy for seasoned equity offerings. It does not materially affect our results.
} 
buy-side benefits from the research of sell-side analysts. In some of the following sections of this paper these abnormal returns will be contemporaneous with the behavior of buy-side analysts, and in other cases we compute them subsequent to the quarter in which the behavior occurs. For each section, we clarify whether the returns that we examine are contemporaneous or subsequent. In some tables we also provide abnormal returns for the first and last months of the contemporaneous quarters. We alternatively compute quarterly abnormal returns using the CAPM, Fama and French (1993) three-factor model, and Carhart (1997) four-factor model as our benchmarks. In all cases, we use monthly returns data as the basis for these calculations. We download the factors from Kenneth French's website. For example, to compute the buy-side analysts' upgraded stocks' abnormal returns, we first identity the stocks upgraded/downgraded as detailed above and then form an equally-weighted and a value-weighted portfolio of those stocks. We then regress the excess returns of these two portfolios on the factors prescribed under the CAPM, Fama-French three-factor model, and Carhart (1997) four-factor model. For instance, to determine the fourfactor abnormal return of an equally-weighted portfolio of upgraded stocks for buy-side analyst "i", we regress his or her portfolio's quarterly excess return on the three factors of Fama and French (1993) and the momentum factor in Carhart (1997) as follows: $r_{i, t}-r_{f, t}=\alpha_{i}+\beta_{i}$ $\left(r_{m, t}-r_{f, t}\right)+\gamma_{i}\left(s m b_{t}\right)+\delta_{i}\left(h_{t}\right)+\omega_{i}\left(m_{t}\right)+\varepsilon_{i, t}$, where $r_{i, t}-r_{f, t}$ is the excess return of equally-weighted portfolios of stocks upgraded by analyst $\mathrm{i}$ over the risk-free rate in quarter $\mathrm{t}$; the first factor, $\mathrm{r}_{\mathrm{m}}$, $t-r_{f, t}$ (or $R_{M R F}$ ) denotes the return in excess of the valueweighted return on all NYSE, AMEX and NASDAQ stocks over the three-month T-bill yield in quarter $\mathrm{t}$; the second factor, $\mathrm{smb}_{\mathrm{t}}$, is the difference between the returns of small and large capitalization stocks in quarter $\mathrm{t}$; the third factor, $\mathrm{hml}_{\mathrm{t}}$, is the difference between the returns of high and low book-to-market stocks in quarter t; and the fourth factor, $\operatorname{mom}_{t}$, is the difference between the returns of stocks with high and low recent returns in quarter t. The intercept of the above time-series regressions is analyst i's alpha or abnormal return. Following a similar procedure, we compute an analyst's Fama-French three-factor and CAPM abnormal returns. We then compute the alpha for analyst i's downgraded stocks as well as for a zero-investment portfolio that goes long in analyst i's upgraded stock and short in his or her downgraded stocks. We repeat the entire analysis for value-weighted portfolios. Our analysis of the investment performance of buy-side analysts is based on the crosssectional mean of analysts' abnormal returns as calculated above. For sell-side analysts, we simply compute the alpha for portfolios of stocks that were upgraded or downgraded in a particular quarter as indicated by the change in the sell-side analysts' consensus recommendations. As we did with buy-side analysts, we form zeroinvestment portfolios by going long in upgraded and short in downgraded stocks. The analysis is again conducted for both equally-weighted and value-weighted portfolios using the CAPM, FamaFrench three-factor, and Carhart four-factor models.

\section{Results and discussion}

\subsection{When do buy-side analysts and sell-side analysts change recommendations?}

\subsubsection{Descriptive statistics}

Table 1 provides descriptive statistics for our sample of institutions and analysts. Not surprisingly, the distribution among institutions is fairly even between purchases and sales, as is the distribution among sell-side analysts between recommendation upgrades and downgrades. Panel B gives a further breakdown of the managers, portfolio sizes, and portfolio turnover for our subsample of institutions. Though there is a far greater number of managers within the brokerage firm and "all other" subgroups, the highest turnover and largest portfolios belong to the mutual fund subgroup. While the turnover numbers are expected

\section{Table 1}

Descriptive statistics.

The table below reports some of the main features of our sample. The sample period is from the first quarter of 1994 to the last quarter of 2009. We derive buy-side analyst data from the changes in quarterly institutional holding data for each manager reported in $13 \mathrm{~F}$ as detailed in the text, and sell-side analyst data from the IBES detailed recommendation files. We determine whether a stock was upgraded or downgraded by sell-side analysts (which results in a "change in consensus recommendation") for the end of each quarter. To compute the consensus recommendation for a stock, we average all outstanding analyst recommendations that are less than one year old. In Panel A we report the distribution of upgrades, downgrades, and non-changes for buy-side and sell-side analysts in a typical quarter. In Panel B we report the size of the portfolio managed by a typical fund manager and turnover classified by the category of institution. The portfolio turnover is computed for each manager in each quarter per the formula given in the CRSP files.

\begin{tabular}{|c|c|c|c|c|c|c|c|}
\hline \multicolumn{8}{|c|}{ Panel A: Buy-side and sell-side analysts' recommendation changes } \\
\hline \multicolumn{3}{|c|}{ Trade/recommendation } & \multicolumn{2}{|c|}{$\begin{array}{l}\text { Buy-side analysts' } \\
\text { recommendations }\end{array}$} & & \multicolumn{2}{|c|}{$\begin{array}{l}\text { Sell-side analysts' } \\
\text { recommendations }\end{array}$} \\
\hline \multirow{3}{*}{\multicolumn{2}{|c|}{$\begin{array}{l}\text { Buy/upgrade } \\
\text { No change } \\
\text { Sell/downgrade }\end{array}$}} & \multicolumn{3}{|c|}{$50.04 \%$} & & \multicolumn{2}{|l|}{$39.72 \%$} \\
\hline & & \multicolumn{3}{|c|}{$\mathrm{N} / \mathrm{A}$} & & \multicolumn{2}{|l|}{$24.37 \%$} \\
\hline & & \multicolumn{3}{|c|}{$49.96 \%$} & & \multicolumn{2}{|l|}{$35.90 \%$} \\
\hline \multicolumn{8}{|c|}{ Panel B: Managers' portfolio sizes and turnover } \\
\hline \multirow[t]{2}{*}{$\begin{array}{l}\text { Type of } \\
\text { institution }\end{array}$} & \multirow{2}{*}{$\begin{array}{l}\text { \# of } \\
\text { unique } \\
\text { managers }\end{array}$} & \multicolumn{3}{|c|}{$\begin{array}{l}\text { Portfolio size } \\
\text { (in millions of dollars) }\end{array}$} & \multicolumn{3}{|c|}{ Portfolio turnover } \\
\hline & & Mean & Median & $\begin{array}{l}\text { Standard } \\
\text { deviation }\end{array}$ & Mean & Median & $\begin{array}{l}\text { Standard } \\
\text { deviation }\end{array}$ \\
\hline Banks & 354 & 8470 & 8593 & 3087 & 23.7 & 20.4 & 8.1 \\
\hline $\begin{array}{l}\text { Insurance } \\
\text { firms }\end{array}$ & 111 & 8465 & 8953 & 2607 & 31.0 & 29.0 & 10.3 \\
\hline $\begin{array}{l}\text { Mutual } \\
\text { funds }\end{array}$ & 139 & 25,781 & 25,308 & 13,809 & 43.9 & 39.6 & 14.5 \\
\hline Brokerage & 2298 & 2537 & 2472 & 793 & 37.5 & 33.6 & 10.9 \\
\hline Others & 2027 & 3218 & 2183 & 2885 & 30.0 & 30.3 & 6.2 \\
\hline All & & 3931 & 4173 & 922 & 35.6 & 31.5 & 9.8 \\
\hline
\end{tabular}

given the incentives that prevail within the mutual fund industry, it should be noted that multiple mutual funds within the same company are aggregated, thus the extremely high portfolio sizes shown for that subgroup of institution.

\subsubsection{Buy-side analysts' recommendations and the performance of institutional portfolios}

We now examine the contemporaneous returns, benchmarked against the CAPM, Fama-French three-factor, and Carhart four-factor models, of portfolios formed on the basis of institutional trading. We use institutional trading as a proxy for buy-side analyst behavior. The results in Table 2 are interesting: portfolios of stocks downgraded by buy-side analysts outperform the three benchmarks in the same quarter, while portfolios of stocks upgraded by buy-side analysts underperform those benchmarks. All of these results are highly significant. Although the underperformance is stronger for equally-weighted portfolios, the value-weighted portfolios are only marginally better. Given the nature of our data it is difficult to say for sure whether buyside upgrades/downgrades on average lead, lag or occur at roughly the same time that the institutional portfolios are generating such excess returns. However, it is notable that for downgraded stocks, which make up the majority of the overall abnormal return to institutions, the highest returns occur in the first month of the quarter (we do not report returns for the second month, but they can be inferred from the rest of the results), and are much higher than in the third month. However, the returns in the first and last months are the sign that is consistent with the quarterly returns for downgraded and upgraded stocks. These results suggest that the recommendations of buy-side analysts are harmful to the portfolios of the institutional traders that they advise.

An alternative explanation is that buy-side analysts have a longer investment horizon than do sell-side analysts or they are contrarian investors, and therefore one should examine the abnormal returns 
Table 2

Profitability of portfolios constructed from contemporaneous changes in buy-side analysts' recommendations.

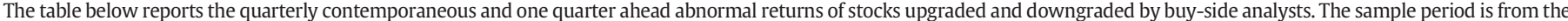

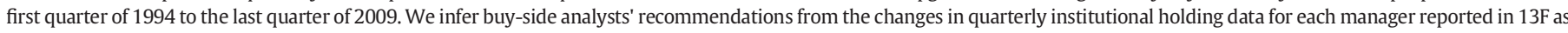

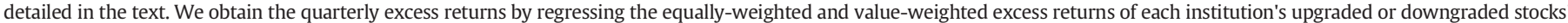

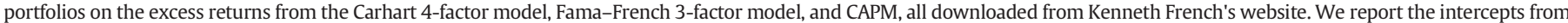
these regressions below. We report t-statistics in parentheses.

\begin{tabular}{|c|c|c|c|c|c|c|c|c|c|c|c|c|}
\hline & \multicolumn{4}{|c|}{ CAPM abnormal return } & \multicolumn{4}{|c|}{ Fama-French abnormal return } & \multicolumn{4}{|c|}{ Carhart abnormal return } \\
\hline & Quarterly & $\begin{array}{l}\text { First } \\
\text { month }\end{array}$ & $\begin{array}{l}\text { Last } \\
\text { month }\end{array}$ & $\begin{array}{l}\text { Next } \\
\text { quarter }\end{array}$ & Quarterly & $\begin{array}{l}\text { First } \\
\text { month }\end{array}$ & $\begin{array}{l}\text { Last } \\
\text { month }\end{array}$ & $\begin{array}{l}\text { Next } \\
\text { quarter }\end{array}$ & Quarterly & $\begin{array}{l}\text { First } \\
\text { month }\end{array}$ & $\begin{array}{l}\text { Last } \\
\text { month }\end{array}$ & $\begin{array}{l}\text { Next } \\
\text { quarter }\end{array}$ \\
\hline Downgraded & $\begin{array}{l}1.98 \\
(33.67)\end{array}$ & $\begin{array}{l}0.79 \\
(30.21)\end{array}$ & $\begin{array}{l}0.38 \\
(19.83)\end{array}$ & $\begin{array}{l}0.26 \\
(8.30)\end{array}$ & $\begin{array}{l}1.55 \\
(30.37)\end{array}$ & $\begin{array}{l}0.93 \\
(34.25)\end{array}$ & $\begin{array}{l}0.08 \\
(4.50)\end{array}$ & $\begin{array}{l}-0.11 \\
(-3.68)\end{array}$ & $\begin{array}{l}1.41 \\
(26.06)\end{array}$ & $\begin{array}{l}0.73 \\
(29.60)\end{array}$ & $\begin{array}{l}0.30 \\
(13.15)\end{array}$ & $\begin{array}{l}-0.08 \\
(-2.34)\end{array}$ \\
\hline Upgraded & $\begin{array}{l}-0.33 \\
(-6.90)\end{array}$ & $\begin{array}{l}-0.17 \\
(-7.76)\end{array}$ & $\begin{array}{l}-0.10 \\
(-5.06)\end{array}$ & $\begin{array}{l}0.59 \\
(18.35)\end{array}$ & $\begin{array}{l}-0.64 \\
(-13.25)\end{array}$ & $\begin{array}{l}-0.06 \\
(-2.72)\end{array}$ & $\begin{array}{l}-0.38 \\
(-18.56)\end{array}$ & $\begin{array}{l}0.19 \\
(6.91)\end{array}$ & $\begin{array}{l}-0.73 \\
(-14.82)\end{array}$ & $\begin{array}{l}-0.20 \\
(-9.10)\end{array}$ & $\begin{array}{l}-0.21 \\
(-9.48)\end{array}$ & $\begin{array}{l}0.15 \\
(4.62)\end{array}$ \\
\hline $\begin{array}{l}\text { Upgraded minus } \\
\text { downgraded }\end{array}$ & $\begin{array}{l}-2.12 \\
(-26.79)\end{array}$ & $\begin{array}{l}-0.89 \\
(-25.01)\end{array}$ & $\begin{array}{l}-0.44 \\
(-17.62)\end{array}$ & $\begin{array}{l}0.30 \\
(9.07)\end{array}$ & $\begin{array}{l}-2.01 \\
(-26.35)\end{array}$ & $\begin{array}{l}-0.91 \\
(-25.02)\end{array}$ & $\begin{array}{l}-0.42 \\
(-16.09)\end{array}$ & $\begin{array}{l}0.27 \\
(8.37)\end{array}$ & $\begin{array}{l}-1.97 \\
(-24.92)\end{array}$ & $\begin{array}{l}-0.86 \\
(-24.52)\end{array}$ & $\begin{array}{l}-0.47 \\
(-15.42)\end{array}$ & $\begin{array}{l}0.20 \\
(5.24)\end{array}$ \\
\hline
\end{tabular}

Mean quarterly and monthly abnormal returns of value-weighted portfolios downgraded and upgraded by buy-side analysts (\%) (t-statistic)

\begin{tabular}{|c|c|c|c|c|c|c|c|c|c|c|c|c|}
\hline & \multicolumn{4}{|c|}{ CAPM abnormal return } & \multicolumn{4}{|c|}{ Fama-French abnormal return } & \multicolumn{4}{|c|}{ Carhart abnormal return } \\
\hline & Quarterly & $\begin{array}{l}\text { First } \\
\text { month }\end{array}$ & $\begin{array}{l}\text { Last } \\
\text { month }\end{array}$ & $\begin{array}{l}\text { Next } \\
\text { quarter }\end{array}$ & Quarterly & $\begin{array}{l}\text { First } \\
\text { month }\end{array}$ & $\begin{array}{l}\text { Last } \\
\text { month }\end{array}$ & $\begin{array}{l}\text { Next } \\
\text { quarter }\end{array}$ & Quarterly & $\begin{array}{l}\text { First } \\
\text { month }\end{array}$ & $\begin{array}{l}\text { Last } \\
\text { month }\end{array}$ & $\begin{array}{l}\text { Next } \\
\text { quarter }\end{array}$ \\
\hline Downgraded & $\begin{array}{l}1.13 \\
(22.89)\end{array}$ & $\begin{array}{l}0.71 \\
(30.52)\end{array}$ & $\begin{array}{l}0.07 \\
(3.96)\end{array}$ & $\begin{array}{l}-0.22 \\
(-7.66)\end{array}$ & $\begin{array}{l}1.10 \\
(24.91)\end{array}$ & $\begin{array}{l}0.68 \\
(27.76)\end{array}$ & $\begin{array}{l}0.23 \\
(12.22)\end{array}$ & $\begin{array}{l}-0.21 \\
(-7.51)\end{array}$ & $\begin{array}{l}0.95 \\
(20.40)\end{array}$ & $\begin{array}{l}0.63 \\
(28.04)\end{array}$ & $\begin{array}{l}0303 \\
(1.22)\end{array}$ & $\begin{array}{l}-0.22 \\
(-6.66)\end{array}$ \\
\hline Upgraded & $\begin{array}{l}-0.85 \\
(-19.56)\end{array}$ & $\begin{array}{l}-0.22 \\
(-10.06)\end{array}$ & $\begin{array}{l}-0.26 \\
(13.15)\end{array}$ & $\begin{array}{l}-0.01 \\
(-0.45)\end{array}$ & $\begin{array}{l}-0.80 \\
(-18.11)\end{array}$ & $\begin{array}{l}-0.25 \\
(-11.61)\end{array}$ & $\begin{array}{l}-0.11 \\
(-5.21)\end{array}$ & $\begin{array}{l}-0.03 \\
(-1.11)\end{array}$ & $\begin{array}{l}-0.87 \\
(-18.89)\end{array}$ & $\begin{array}{l}-0.28 \\
(-12.71)\end{array}$ & $\begin{array}{l}-0.30 \\
(-13.30)\end{array}$ & $\begin{array}{l}-0.07 \\
(-2.26)\end{array}$ \\
\hline $\begin{array}{l}\text { Upgraded minus } \\
\text { downgraded }\end{array}$ & $\begin{array}{l}-1.82 \\
(-26.20)\end{array}$ & $\begin{array}{l}-0.83 \\
(-25.61)\end{array}$ & $\begin{array}{l}-0.30 \\
(-11.97)\end{array}$ & $\begin{array}{l}0.19 \\
(5.55)\end{array}$ & $\begin{array}{l}-1.75 \\
(-26.21)\end{array}$ & $\begin{array}{l}-0.85 \\
(-25.42)\end{array}$ & $\begin{array}{l}-0.31 \\
(-11.73)\end{array}$ & $\begin{array}{l}0.15 \\
(4.67)\end{array}$ & $\begin{array}{l}-1.68 \\
(-24.40)\end{array}$ & $\begin{array}{l}-0.84 \\
(-25.92)\end{array}$ & $\begin{array}{l}-0.25 \\
(-8.07)\end{array}$ & $\begin{array}{l}0.12 \\
(3.18)\end{array}$ \\
\hline
\end{tabular}

from the following quarter as well. These returns, though positive, are tiny compared to the negative returns from the previous quarter, and are in fact smaller than those of just the previous month. Moreover, those positive subsequent-quarter returns may owe in part to price pressure caused by portfolio rebalancing in response to the negative returns occurring in the quarter before. Based on all of this, it seems unlikely that the alternative explanation outlined above can explain the underperformance of institutional trading.

Table 3

Profitability of portfolios constructed from contemporaneous changes in sell-side analysts' recommendations.

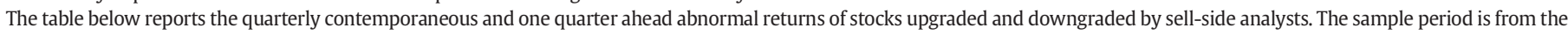

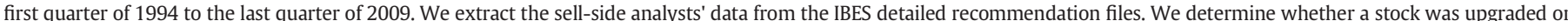

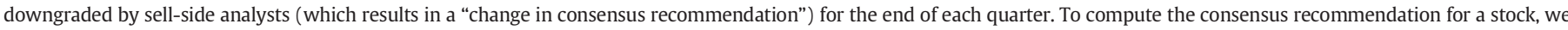

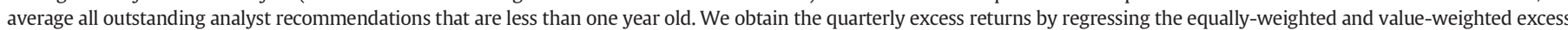

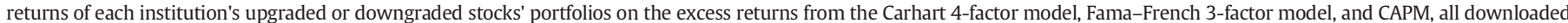
from Kenneth French's website. We report the intercepts from these regressions below. We report t-statistics in parentheses.

\begin{tabular}{|c|c|c|c|c|c|c|c|c|c|c|c|c|}
\hline & \multicolumn{4}{|c|}{ CAPM abnormal return } & \multicolumn{4}{|c|}{ Fama-French abnormal return } & \multicolumn{4}{|c|}{ Carhart abnormal return } \\
\hline & Quarterly & $\begin{array}{l}\text { First } \\
\text { month }\end{array}$ & $\begin{array}{l}\text { Last } \\
\text { month }\end{array}$ & $\begin{array}{l}\text { Next } \\
\text { quarter }\end{array}$ & Quarterly & $\begin{array}{l}\text { First } \\
\text { month }\end{array}$ & $\begin{array}{l}\text { Last } \\
\text { month }\end{array}$ & $\begin{array}{l}\text { Next } \\
\text { quarter }\end{array}$ & Quarterly & $\begin{array}{l}\text { First } \\
\text { month }\end{array}$ & $\begin{array}{l}\text { Last } \\
\text { month }\end{array}$ & $\begin{array}{l}\text { Next } \\
\text { quarter }\end{array}$ \\
\hline Downgraded & $\begin{array}{l}-3.72 \\
(-5.17)\end{array}$ & $\begin{array}{l}-1.58 \\
(-3.13)\end{array}$ & $\begin{array}{l}-1.40 \\
(-4.24)\end{array}$ & $\begin{array}{l}-0.28 \\
(-0.35)\end{array}$ & $\begin{array}{l}-4.28 \\
(-11.97)\end{array}$ & $\begin{array}{l}-0.99 \\
(-3.18)\end{array}$ & $\begin{array}{l}-1.99 \\
(-7.74)\end{array}$ & $\begin{array}{l}-0.92 \\
(-2.79)\end{array}$ & $\begin{array}{l}-3.93 \\
(-9.93)\end{array}$ & $\begin{array}{l}-1.28 \\
(-6.08)\end{array}$ & $\begin{array}{l}-1.08 \\
(-4.46)\end{array}$ & $\begin{array}{l}-0.67 \\
(-1.79)\end{array}$ \\
\hline No change & $\begin{array}{l}0.91 \\
(1.14)\end{array}$ & $\begin{array}{l}0.28 \\
(0.52)\end{array}$ & $\begin{array}{l}0.49 \\
(1.33)\end{array}$ & $\begin{array}{l}0.39 \\
(0.47)\end{array}$ & $\begin{array}{l}0.28 \\
(0.94)\end{array}$ & $\begin{array}{l}0.97 \\
(3.62)\end{array}$ & $\begin{array}{l}-0.16 \\
(-0.73)\end{array}$ & $\begin{array}{l}-0.25 \\
(-0.74)\end{array}$ & $\begin{array}{l}0.27 \\
(0.79)\end{array}$ & $\begin{array}{l}0.75 \\
(3.63)\end{array}$ & $\begin{array}{l}0.36 \\
(1.41)\end{array}$ & $\begin{array}{l}-0.00 \\
(-0.1)\end{array}$ \\
\hline Upgraded & $\begin{array}{l}4.85 \\
(5.94)\end{array}$ & $\begin{array}{l}1.60 \\
(3.64)\end{array}$ & $\begin{array}{l}1.53 \\
(5.47)\end{array}$ & $\begin{array}{l}1.00 \\
(1.65)\end{array}$ & $\begin{array}{l}4.22 \\
(10.09)\end{array}$ & $\begin{array}{l}2.10 \\
(8.10)\end{array}$ & $\begin{array}{l}1.00 \\
(4.96)\end{array}$ & $\begin{array}{l}0.50 \\
(2.30)\end{array}$ & $\begin{array}{l}3.97 \\
(8.41)\end{array}$ & $\begin{array}{l}1.87 \\
(9.94)\end{array}$ & $\begin{array}{l}1.30 \\
(5.37)\end{array}$ & $\begin{array}{l}0.38 \\
(1.54)\end{array}$ \\
\hline $\begin{array}{l}\text { Upgraded minus } \\
\text { downgraded }\end{array}$ & $\begin{array}{l}8.56 \\
(14.59)\end{array}$ & $\begin{array}{l}3.19 \\
(11.42)\end{array}$ & $\begin{array}{l}2.93 \\
(12.38)\end{array}$ & $\begin{array}{l}1.28 \\
(3.66)\end{array}$ & $\begin{array}{l}8.50 \\
(14.27)\end{array}$ & $\begin{array}{l}3.09 \\
(11.29)\end{array}$ & $\begin{array}{l}3.00 \\
(11.97)\end{array}$ & $\begin{array}{l}1.42 \\
(4.47)\end{array}$ & $\begin{array}{l}7.90 \\
(12.01)\end{array}$ & $\begin{array}{l}3.15 \\
(11.46)\end{array}$ & $\begin{array}{l}2.38 \\
(8.62)\end{array}$ & $\begin{array}{l}1.05 \\
(2.98)\end{array}$ \\
\hline
\end{tabular}

Mean quarterly and monthly abnormal returns of value-weighted portfolios downgraded and upgraded by sell-side analysts (\%) ( $t$-statistic)

\begin{tabular}{|c|c|c|c|c|c|c|c|c|c|c|c|c|}
\hline & \multicolumn{4}{|c|}{ CAPM abnormal return } & \multicolumn{4}{|c|}{ Fama-French abnormal return } & \multicolumn{4}{|c|}{ Carhart abnormal return } \\
\hline & Quarterly & $\begin{array}{l}\text { First } \\
\text { month }\end{array}$ & $\begin{array}{l}\text { Last } \\
\text { month }\end{array}$ & $\begin{array}{l}\text { Next } \\
\text { quarter }\end{array}$ & Quarterly & $\begin{array}{l}\text { First } \\
\text { month }\end{array}$ & $\begin{array}{l}\text { Last } \\
\text { month }\end{array}$ & $\begin{array}{l}\text { Next } \\
\text { quarter }\end{array}$ & Quarterly & $\begin{array}{l}\text { First } \\
\text { month }\end{array}$ & $\begin{array}{l}\text { Last } \\
\text { month }\end{array}$ & $\begin{array}{l}\text { Next } \\
\text { quarter }\end{array}$ \\
\hline Downgraded & $\begin{array}{l}-1.92 \\
(-10.52)\end{array}$ & $\begin{array}{l}-0.56 \\
(-4.76)\end{array}$ & $\begin{array}{l}-0.81 \\
(-7.82)\end{array}$ & $\begin{array}{l}0.20 \\
(0.85)\end{array}$ & $\begin{array}{l}-1.87 \\
(-10.68)\end{array}$ & $\begin{array}{l}-0.60 \\
(-5.00)\end{array}$ & $\begin{array}{l}-0.84 \\
(-7.77)\end{array}$ & $\begin{array}{l}0.10 \\
(0.48)\end{array}$ & $\begin{array}{l}-1.86 \\
(-9.36)\end{array}$ & $\begin{array}{l}-0.63 \\
(-5.30)\end{array}$ & $\begin{array}{l}-0.57 \\
(-4.81)\end{array}$ & $\begin{array}{l}0.37 \\
(1.68)\end{array}$ \\
\hline No change & $\begin{array}{l}0.19 \\
(0.61)\end{array}$ & $\begin{array}{l}-0.43 \\
(-2.45)\end{array}$ & $\begin{array}{l}0.43 \\
(2.24)\end{array}$ & $\begin{array}{l}-0.43 \\
(-1.22)\end{array}$ & $\begin{array}{l}0.13 \\
(0.49)\end{array}$ & $\begin{array}{l}-0.33 \\
(-1.97)\end{array}$ & $\begin{array}{l}0.22 \\
(1.41)\end{array}$ & $\begin{array}{l}-0.55 \\
(-1.69)\end{array}$ & $\begin{array}{l}-0.10 \\
(-0.33)\end{array}$ & $\begin{array}{l}-0.27 \\
(-1.64)\end{array}$ & $\begin{array}{l}-0.17 \\
(-1.01)\end{array}$ & $\begin{array}{l}-0.59 \\
(-1.57)\end{array}$ \\
\hline Upgraded & $\begin{array}{l}1.96 \\
(9.70)\end{array}$ & $\begin{array}{l}0.72 \\
(6.03)\end{array}$ & $\begin{array}{l}0.76 \\
(4.85)\end{array}$ & $\begin{array}{l}-0.31 \\
(1.46)\end{array}$ & $\begin{array}{l}1.92 \\
(9.60)\end{array}$ & $\begin{array}{l}0.71 \\
(5.75)\end{array}$ & $\begin{array}{l}0.81 \\
(5.03)\end{array}$ & $\begin{array}{l}-0.24 \\
(-1.20)\end{array}$ & $\begin{array}{l}1.85 \\
(8.13)\end{array}$ & $\begin{array}{l}0.73 \\
(5.84)\end{array}$ & $\begin{array}{l}0.72 \\
(3.63)\end{array}$ & $\begin{array}{l}-0.40 \\
(-1.78)\end{array}$ \\
\hline $\begin{array}{l}\text { Upgraded minus } \\
\text { downgraded }\end{array}$ & $\begin{array}{l}3.88 \\
(10.76)\end{array}$ & $\begin{array}{l}1.29 \\
(5.67)\end{array}$ & $\begin{array}{l}1.58 \\
(7.29)\end{array}$ & $\begin{array}{l}-0.51 \\
(-1.37)\end{array}$ & $\begin{array}{l}3.79 \\
(10.68)\end{array}$ & $\begin{array}{l}1.30 \\
(5.58)\end{array}$ & $\begin{array}{l}1.65 \\
(7.19)\end{array}$ & $\begin{array}{l}-0.34 \\
(-1.03)\end{array}$ & $\begin{array}{l}3.71 \\
(9.19)\end{array}$ & $\begin{array}{l}1.36 \\
(5.78)\end{array}$ & $\begin{array}{l}1.29 \\
(4.75)\end{array}$ & $\begin{array}{l}-0.77 \\
(-2.17)\end{array}$ \\
\hline
\end{tabular}


3.1.3. Changes in sell-side analyst recommendations and the performance of their portfolios

As shown in Table 3, the contemporaneous performance of portfolios constructed from changes in sell-side recommendations is very different from that of portfolios constructed in accordance with institutional trading. Sell-side analysts' portfolios perform profitably. When analysts downgrade, the same-quarter excess returns to those stocks are significantly negative, and when they upgrade, the excess returns are significantly positive. We also observe that the quarterly alphas are quite large. This is the case for both equally-weighted and value-weighted portfolios, and the results hold for the Carhart fourfactor as well as Fama-French three-factor and CAPM benchmarks. What is also interesting to note is that unlike the intra-quarter buyside returns, the returns to the sell-side are, on average, evenly distributed throughout the three months. We revisit this result in the next section of this study, in which we compare the performance of portfolios consistent with contemporaneous buy- and sell-side recommendation activities. Last, the returns in the following quarter remain positive for equally-weighted portfolios and are negative but relatively small for value-weighted portfolios. This, along with the same-quarter results, suggests that sell-side analysts enjoy a greater advantage within the domain of small-cap stocks, and that their overall advantage against buy-side analysts persists through the following quarter.

\subsubsection{Institutional trading for different types of analyst behavior}

One could argue that institutions rely on sell-side analysts in addition to their own analysts when they consider making trades. If this is the case, then the underperformance of institutional portfolios may not be entirely attributable to those buy-side analysts. To tease out the performance that could be ascribed to buy-side analysts, we segment the institutional portfolios into portfolios that are consistent with sell-side analysts' recommendations and portfolios that trade against sell-side analysts' recommendations. We also create a group for the cases in which institutions traded in a quarter when sell-side analysts collectively did not change their consensus recommendation. We argue that institutional portfolios that are inconsistent with sell-side analyst recommendation changes offer us the cleanest sample where we can isolate the effect of buy-side analysts' recommendations. Specifically, we examine the relative performance of portfolios of stocks which were bought by institutions (presumably at the behest of buyside analysts) but which were downgraded by sell-side analysts at the same time. Similarly, we examine the performance of portfolios of stocks that were sold by institutions (at the behest of buy-side analysts) but which were simultaneously upgraded by sell-side analysts.

In Table 4, we report the contemporaneous excess returns for portfolios when institutions trade, conditional on the behavior of sell-side analysts. Panel A examines the case where institutional trading is done in the opposite direction of the change in the analysts' consensus recommendation (either institutions are net buyers in the same quarter that sell-side analysts downgrade the stock or institutions are net sellers in the same quarter that sell-side analysts upgrade the stock). In this situation, the portfolios generate statistical and economic underperformance of a severe magnitude for both upgraded and downgraded stocks. The difference between the equally-weighted and value-weighted portfolios suggests that much of this result is concentrated in smaller stocks, but there are very high levels of significance for the value-weighted portfolio returns as well. In comparison to Table 2, the underperformance is far more significant and consistent with the idea that buy-side analyst recommendations are harmful to the interests of institutional investors. Moreover, the abnormal returns in Table 4 are fairly uniform across the three months of the quarter and are highly significant, both economically and statistically, everywhere. Because the negative "alpha" is not concentrated in the first month and moreover remains substantially negative in the third month $(-1.2 \%$ to- $1.7 \%)$, we can say with a fair degree of certainty that institutional investors do not appear to employ a systematic, contrarian approach of buying stocks after they have decreased in value or selling stocks after they have increased in value. Moreover, some research finds that it is the buy-side that tends to follow the sell-side rather than the other way around; institutional trading is often done in response to changes in analyst recommendations (Busse et al., 2012). All of this suggests that contrarianism is not a primary, or perhaps even significant, reason for why institutions trade stocks. Further, the reversal seen in the following month is, as in Table 2, miniscule in relation to the abnormal return from the previous quarter, and nonexistent for value-weighted "up-minus-down" portfolios. This suggests that differential investment horizons between buy-side and sell-side analysts are not likely to be a key factor in our results. The evidence instead indicates that on balance, institutional trades that contradict sell-side analyst recommendations are unprofitable.

Panel B reports the contemporaneous abnormal market returns for the case where institutions trade stocks for which there is no concurrent change in the consensus sell-side analyst recommendation. Here again the underperformance is significant at least on a within-quarter basis. When institutions buy, the returns on the stocks that they buy are negative and in most cases significant, and when institutions sell, those stocks' returns are positive and highly significant. Although zero-investment portfolios long in upgraded and short in downgraded stocks show significant underperformance, the primary culprit seems to be the group of downgraded stocks. We do not observe much difference between the abnormal returns of the value- and equally-weighted portfolios. For this subset of trades, the returns are smaller (in absolute value) in the third month of the quarter, but are still significantly negative, suggesting that at least some of the overall negative return probably succeeds the trade. These results contrast somewhat with earlier studies by Chen, Jegadeesh, and Wermers (2000) and Binay (2005) which also use Thomson 13F holdings data. In addition, the existence of a "reversal" (to the extent that there is one) in the following quarter is relatively small.

Panel $\mathrm{C}$ addresses the case where institutions trade in accordance with concurrent changes in the sell-side consensus recommendation. Here the results are opposite those in Panels A and B; institutions generally sell stocks that are falling and buy stocks that are rising, adding to the positive abnormal returns to their portfolios overall. The results are somewhat uniform across the three months of the quarter. This indicates that while buy-side analysts' recommendations lead to the underperformance of institutional portfolios, this underperformance is mitigated a bit when their recommendations are in agreement with revisions made by sell-side analysts. However, it also could be argued that buy-side analysts' contribution to institutional profitability is most visible when they go against sell-side analysts' recommendations. In addition, buy-side trading is likely a better proxy for buy-side analyst behavior when the trades contradict what sell-side analysts are saying than when they do not. For these reasons, in our subsequent analysis we focus on the subset of buy-side trades that go against sell-side analysts' recommendations in order to explore other aspects of buyside analysts' performance.

\subsubsection{Excess stock returns and institutional portfolio characteristics}

Our results indicate that portfolios built from buy-side recommendations contemporaneously underperform the market. Thus, it is likely that a typical buy-side analyst most likely harms the performance of the institution for which he or she works. However, it is additionally important to examine whether there are cross-sectional differences in the abilities of buy-side analysts. For example, it may be revealing to examine the contemporaneous returns of the portfolios of stocks traded by large institutions (as proxied by portfolio size) based on the possibility that larger institutions are able to hire more competent analysts than smaller institutions. There could also be cross-sectional differences between analysts with regard to portfolio turnover; it might be the case that more competent analysts issue recommendations more (or less) frequently than do less competent analysts. Some of the cross-sectional 
Table 4

Contemporaneous profitability of portfolios constructed from changes in buy-side analysts' recommendations conditioned on changes in sell-side recommendations.

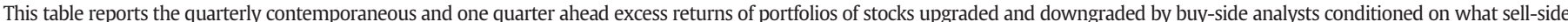

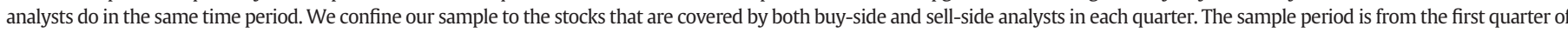

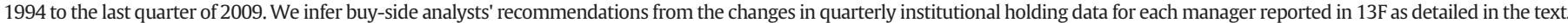

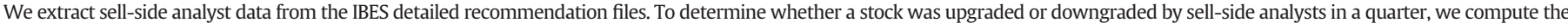

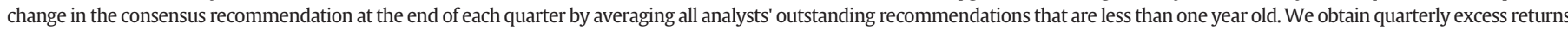

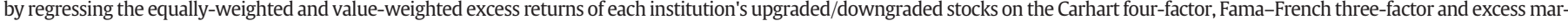
ket returns, all downloaded from Kenneth French's website. The intercepts from these regressions are reported below (t-statistics are in parentheses).

Panel A: Mean quarterly abnormal returns of equally-weighted portfolios upgraded/downgraded by buy-side analysts when the sell-side consensus analyst recommendation simultaneously changes in the opposite direction (\%) (t-statistic)

\begin{tabular}{|c|c|c|c|c|c|c|c|c|c|c|c|c|}
\hline & \multicolumn{4}{|c|}{ CAPM abnormal return } & \multicolumn{4}{|c|}{ Fama-French abnormal return } & \multicolumn{4}{|c|}{ Carhart abnormal return } \\
\hline & Quarterly & $\begin{array}{l}\text { First } \\
\text { month }\end{array}$ & $\begin{array}{l}\text { Last } \\
\text { month }\end{array}$ & $\begin{array}{l}\text { Next } \\
\text { quarter }\end{array}$ & Quarterly & $\begin{array}{l}\text { First } \\
\text { month }\end{array}$ & $\begin{array}{l}\text { Last } \\
\text { month }\end{array}$ & $\begin{array}{l}\text { Next } \\
\text { quarter }\end{array}$ & Quarterly & $\begin{array}{l}\text { First } \\
\text { month }\end{array}$ & $\begin{array}{l}\text { Last } \\
\text { month }\end{array}$ & $\begin{array}{l}\text { Next } \\
\text { quarter }\end{array}$ \\
\hline Down & $\begin{array}{l}4.63 \\
(71.36)\end{array}$ & $\begin{array}{l}1.93 \\
(61.42)\end{array}$ & $\begin{array}{l}1.28 \\
(56.86)\end{array}$ & $\begin{array}{l}0.15 \\
(4.28)\end{array}$ & $\begin{array}{l}4.19 \\
(70.77)\end{array}$ & $\begin{array}{l}2.01 \\
(60.33)\end{array}$ & $\begin{array}{l}-1.27 \\
(-49.74)\end{array}$ & $\begin{array}{l}-0.05 \\
(-1.45)\end{array}$ & $\begin{array}{l}3.86 \\
(61.55)\end{array}$ & $\begin{array}{l}-1.10 \\
(-37.04)\end{array}$ & $\begin{array}{l}-0.88 \\
(-31.59)\end{array}$ & $\begin{array}{l}-0.19 \\
(-4.90)\end{array}$ \\
\hline Up & $\begin{array}{l}-2.65 \\
(-41.82)\end{array}$ & $\begin{array}{l}-1.05 \\
(-35.26)\end{array}$ & $\begin{array}{l}-1.00 \\
(-42.23)\end{array}$ & $\begin{array}{l}0.57 \\
(16.56)\end{array}$ & $\begin{array}{l}-2.88 \\
(-44.32)\end{array}$ & $\begin{array}{l}-0.96 \\
(-32.85)\end{array}$ & $\begin{array}{l}1.02 \\
(45.34)\end{array}$ & $\begin{array}{l}0.12 \\
(3.78)\end{array}$ & $\begin{array}{l}-2.91 \\
(-43.43)\end{array}$ & $\begin{array}{l}1.82 \\
(60.19)\end{array}$ & $\begin{array}{l}1.05 \\
(36.11)\end{array}$ & $\begin{array}{l}0.12 \\
(3.43)\end{array}$ \\
\hline $\begin{array}{l}\text { Up } \\
\text { minus down }\end{array}$ & $\begin{array}{l}-6.19 \\
(-30.46)\end{array}$ & $\begin{array}{l}-2.16 \\
(-49.06)\end{array}$ & $\begin{array}{l}-1.68 \\
(-56.07)\end{array}$ & $\begin{array}{l}0.32 \\
(9.28)\end{array}$ & $\begin{array}{l}-6.00 \\
(-59.89)\end{array}$ & $\begin{array}{l}-2.17 \\
(-48.92)\end{array}$ & $\begin{array}{l}-1.70 \\
(-53.98)\end{array}$ & $\begin{array}{l}0.11 \\
(3.37)\end{array}$ & $\begin{array}{l}-5.74 \\
(-56.67)\end{array}$ & $\begin{array}{l}-2.14 \\
(-49.74)\end{array}$ & $\begin{array}{l}-1.42 \\
(-42.50)\end{array}$ & $\begin{array}{l}0.23 \\
(5.83)\end{array}$ \\
\hline
\end{tabular}

Mean quarterly abnormal returns of value-weighted portfolios upgraded/downgraded by buy-side analysts when the sell-side consensus analyst recommendation simultaneously changes in the opposite direction (\%) (t-statistic)

\begin{tabular}{|c|c|c|c|c|c|c|c|c|c|c|c|c|}
\hline & \multicolumn{4}{|c|}{ CAPM abnormal return } & \multicolumn{4}{|c|}{ Fama-French abnormal return } & \multicolumn{4}{|c|}{ Carhart abnormal return } \\
\hline & Quarterly & $\begin{array}{l}\text { First } \\
\text { month }\end{array}$ & $\begin{array}{l}\text { Last } \\
\text { month }\end{array}$ & $\begin{array}{l}\text { Next } \\
\text { quarter }\end{array}$ & Quarterly & $\begin{array}{l}\text { First } \\
\text { month }\end{array}$ & $\begin{array}{l}\text { Last } \\
\text { month }\end{array}$ & $\begin{array}{l}\text { Next } \\
\text { quarter }\end{array}$ & Quarterly & $\begin{array}{l}\text { First } \\
\text { month }\end{array}$ & $\begin{array}{l}\text { Last } \\
\text { month }\end{array}$ & $\begin{array}{l}\text { Next } \\
\text { quarter }\end{array}$ \\
\hline Down & $\begin{array}{l}1.87 \\
(32.82)\end{array}$ & $\begin{array}{l}1.48 \\
(51.29)\end{array}$ & $\begin{array}{l}0.97 \\
(44.00)\end{array}$ & $\begin{array}{l}0.06 \\
(1.23)\end{array}$ & $\begin{array}{l}1.72 \\
(8.62)\end{array}$ & $\begin{array}{l}-0.81 \\
(-29.60)\end{array}$ & $\begin{array}{l}-0.89 \\
(-35.21)\end{array}$ & $\begin{array}{l}-0.03 \\
(-0.73)\end{array}$ & $\begin{array}{l}1.32 \\
(22.90)\end{array}$ & $\begin{array}{l}-0.89 \\
(-32.23)\end{array}$ & $\begin{array}{l}-0.62 \\
(-22.24)\end{array}$ & $\begin{array}{l}-0.12 \\
(-2.17)\end{array}$ \\
\hline Up & $\begin{array}{l}0.01 \\
(0.14)\end{array}$ & $\begin{array}{l}-0.79 \\
(-28.26)\end{array}$ & $\begin{array}{l}-0.96 \\
(-41.27)\end{array}$ & $\begin{array}{l}-0.02 \\
(-0.40)\end{array}$ & $\begin{array}{l}-0.12 \\
(-2.36)\end{array}$ & $\begin{array}{l}1.46 \\
(46.99)\end{array}$ & $\begin{array}{l}1.04 \\
(46.05)\end{array}$ & $\begin{array}{l}-0.14 \\
(-3.40)\end{array}$ & $\begin{array}{l}-0.38 \\
(-6.99)\end{array}$ & $\begin{array}{l}1.44 \\
(50.61)\end{array}$ & $\begin{array}{l}1.01 \\
(34.99)\end{array}$ & $\begin{array}{l}-0.23 \\
(-4.66)\end{array}$ \\
\hline Up minus down & $\begin{array}{l}-1.54 \\
(-35.69)\end{array}$ & $\begin{array}{l}-1.62 \\
(-43.53)\end{array}$ & $\begin{array}{l}-1.41 \\
(-50.43)\end{array}$ & $\begin{array}{l}-0.07 \\
(-1.49)\end{array}$ & $\begin{array}{l}-1.51 \\
(-24.84)\end{array}$ & $\begin{array}{l}-1.64 \\
(-43.29)\end{array}$ & $\begin{array}{l}-1.42 \\
(-48.53)\end{array}$ & $\begin{array}{l}-0.06 \\
(-1.22)\end{array}$ & $\begin{array}{l}-1.43 \\
(-19.30)\end{array}$ & $\begin{array}{l}-1.68 \\
(-45.80)\end{array}$ & $\begin{array}{l}-1.20 \\
(-37.56)\end{array}$ & $\begin{array}{l}-0.05 \\
(-0.95)\end{array}$ \\
\hline
\end{tabular}

Panel B: Mean quarterly abnormal returns of equally-weighted portfolios upgraded/downgraded by buy-side analysts when there is no corresponding change in sell-side analysts' consensus recommendation (\%) (t-statistic)

\begin{tabular}{|c|c|c|c|c|c|c|c|c|c|c|c|c|}
\hline & \multicolumn{4}{|c|}{ CAPM abnormal return } & \multicolumn{4}{|c|}{ Fama-French abnormal return } & \multicolumn{4}{|c|}{ Carhart abnormal return } \\
\hline & Quarterly & $\begin{array}{l}\text { First } \\
\text { month }\end{array}$ & $\begin{array}{l}\text { Last } \\
\text { month }\end{array}$ & $\begin{array}{l}\text { Next } \\
\text { quarter }\end{array}$ & Quarterly & $\begin{array}{l}\text { First } \\
\text { month }\end{array}$ & $\begin{array}{l}\text { Last } \\
\text { month }\end{array}$ & $\begin{array}{l}\text { Next } \\
\text { quarter }\end{array}$ & Quarterly & $\begin{array}{l}\text { First } \\
\text { month }\end{array}$ & $\begin{array}{l}\text { Last } \\
\text { month }\end{array}$ & $\begin{array}{l}\text { Next } \\
\text { quarter }\end{array}$ \\
\hline Down & $\begin{array}{l}2.55 \\
(37.33)\end{array}$ & $\begin{array}{l}0.81 \\
(23.97)\end{array}$ & $\begin{array}{l}0.82 \\
(29.46)\end{array}$ & $\begin{array}{l}0.50 \\
(9.53)\end{array}$ & $\begin{array}{l}1.99 \\
(31.52)\end{array}$ & $\begin{array}{l}1.04 \\
(28.72)\end{array}$ & $\begin{array}{l}0.37 \\
(12.23)\end{array}$ & $\begin{array}{l}0.04 \\
(0.75)\end{array}$ & $\begin{array}{l}-0.35 \\
(-6.18)\end{array}$ & $\begin{array}{l}0.83 \\
(24.92)\end{array}$ & $\begin{array}{l}0.37 \\
(9.77)\end{array}$ & $\begin{array}{l}0.06 \\
(0.99)\end{array}$ \\
\hline Up & $\begin{array}{l}0.33 \\
(6.00)\end{array}$ & $\begin{array}{l}-0.12 \\
(-4.63)\end{array}$ & $\begin{array}{l}0.38 \\
(14.77)\end{array}$ & $\begin{array}{l}0.73 \\
(13.90)\end{array}$ & $\begin{array}{l}-0.10 \\
(-1.95)\end{array}$ & $\begin{array}{l}0.07 \\
(2.50)\end{array}$ & $\begin{array}{l}-0.05 \\
(-2.03)\end{array}$ & $\begin{array}{l}0.23 \\
(5.05)\end{array}$ & $\begin{array}{l}1.66 \\
(23.37)\end{array}$ & $\begin{array}{l}-0.07 \\
(-2.86)\end{array}$ & $\begin{array}{l}-0.08 \\
(-2.68)\end{array}$ & $\begin{array}{l}0.19 \\
(3.50)\end{array}$ \\
\hline Up minus down & $\begin{array}{l}-1.85 \\
(-33.74)\end{array}$ & $\begin{array}{l}-0.54 \\
(-19.49)\end{array}$ & $\begin{array}{l}-0.25 \\
(-11.66)\end{array}$ & $\begin{array}{l}0.20 \\
(3.82)\end{array}$ & $\begin{array}{l}-1.28 \\
(-27.60)\end{array}$ & $\begin{array}{l}-0.56 \\
(-19.63)\end{array}$ & $\begin{array}{l}-0.24 \\
(-10.32)\end{array}$ & $\begin{array}{l}-0.25 \\
(-11.66)\end{array}$ & $\begin{array}{l}-1.22 \\
(-31.14)\end{array}$ & $\begin{array}{l}-0.52 \\
(-19.54)\end{array}$ & $\begin{array}{l}-0.27 \\
(-9.71)\end{array}$ & $\begin{array}{l}0.15 \\
(2.58)\end{array}$ \\
\hline
\end{tabular}

Mean quarterly abnormal returns of value-weighted portfolios upgraded/downgraded by buy-side analysts when there is no corresponding change in sell-side analysts' consensus recommendation (\%) (t-statistic)

\begin{tabular}{|c|c|c|c|c|c|c|c|c|c|c|c|c|}
\hline & \multicolumn{4}{|c|}{ CAPM abnormal return } & \multicolumn{4}{|c|}{ Fama-French abnormal return } & \multicolumn{4}{|c|}{ Carhart abnormal return } \\
\hline & Quarterly & $\begin{array}{l}\text { First } \\
\text { month }\end{array}$ & $\begin{array}{l}\text { Last } \\
\text { month }\end{array}$ & $\begin{array}{l}\text { Next } \\
\text { quarter }\end{array}$ & Quarterly & $\begin{array}{l}\text { First } \\
\text { month }\end{array}$ & $\begin{array}{l}\text { Last } \\
\text { month }\end{array}$ & $\begin{array}{l}\text { Next } \\
\text { quarter }\end{array}$ & Quarterly & $\begin{array}{l}\text { First } \\
\text { month }\end{array}$ & $\begin{array}{l}\text { Last } \\
\text { month }\end{array}$ & $\begin{array}{l}\text { Next } \\
\text { quarter }\end{array}$ \\
\hline Down & $\begin{array}{l}2.02 \\
(32.79)\end{array}$ & $\begin{array}{l}0.57 \\
(18.29)\end{array}$ & $\begin{array}{l}0.66 \\
(24.30)\end{array}$ & $\begin{array}{l}0.08 \\
(1.63)\end{array}$ & $\begin{array}{l}-0.18 \\
(-3.51)\end{array}$ & $\begin{array}{l}0.58 \\
(17.53)\end{array}$ & $\begin{array}{l}0.54 \\
(18.15)\end{array}$ & $\begin{array}{l}-0.02 \\
(-0.40)\end{array}$ & $\begin{array}{l}-0.43 \\
(-7.74)\end{array}$ & $\begin{array}{l}0.53 \\
(17.55)\end{array}$ & $\begin{array}{l}0.24 \\
(6.55)\end{array}$ & $\begin{array}{l}-0.08 \\
(-1.36)\end{array}$ \\
\hline Up & $\begin{array}{l}-0.05 \\
(-0.88)\end{array}$ & $\begin{array}{l}-0.37 \\
(-14.71)\end{array}$ & $\begin{array}{l}0.29 \\
(11.37)\end{array}$ & $\begin{array}{l}-0.00 \\
(-0.04)\end{array}$ & $\begin{array}{l}1.83 \\
(30.92)\end{array}$ & $\begin{array}{l}-0.39 \\
(-14.70)\end{array}$ & $\begin{array}{l}0.18 \\
(6.46)\end{array}$ & $\begin{array}{l}-0.14 \\
(-3.21)\end{array}$ & $\begin{array}{l}1.44 \\
(22.72)\end{array}$ & $\begin{array}{l}-0.42 \\
(-16.10)\end{array}$ & $\begin{array}{l}-0.07 \\
(-2.12)\end{array}$ & $\begin{array}{l}-0.21 \\
(-4.17)\end{array}$ \\
\hline Up minus down & $\begin{array}{l}-1.75 \\
(-23.49)\end{array}$ & $\begin{array}{l}-0.56 \\
(-20.48)\end{array}$ & $\begin{array}{l}-0.21 \\
(-9.72)\end{array}$ & $\begin{array}{l}-0.08 \\
(-1.60)\end{array}$ & $\begin{array}{l}-1.32 \\
(-26.37)\end{array}$ & $\begin{array}{l}-0.57 \\
(-20.59)\end{array}$ & $\begin{array}{l}-0.19 \\
(-8.22)\end{array}$ & $\begin{array}{l}-0.09 \\
(-1.70)\end{array}$ & $\begin{array}{l}-1.17 \\
(-30.51)\end{array}$ & $\begin{array}{l}-0.55 \\
(-21.23)\end{array}$ & $\begin{array}{l}-0.18 \\
(-6.15)\end{array}$ & $\begin{array}{l}-0.09 \\
(-1.46)\end{array}$ \\
\hline
\end{tabular}

Panel C: Mean quarterly abnormal returns of equally-weighted portfolios upgraded/downgraded by buy-side analysts when the sell-side consensus analyst recommendation simultaneously changes in the same direction (\%) (t-statistic)

\begin{tabular}{|c|c|c|c|c|c|c|c|c|c|c|c|c|}
\hline & \multicolumn{4}{|c|}{ CAPM abnormal return } & \multicolumn{4}{|c|}{ Fama-French abnormal return } & \multicolumn{4}{|c|}{ Carhart abnormal return } \\
\hline & Quarterly & $\begin{array}{l}\text { First } \\
\text { month }\end{array}$ & $\begin{array}{l}\text { Last } \\
\text { month }\end{array}$ & $\begin{array}{l}\text { Next } \\
\text { quarter }\end{array}$ & Quarterly & $\begin{array}{l}\text { First } \\
\text { month }\end{array}$ & $\begin{array}{l}\text { Last } \\
\text { month }\end{array}$ & $\begin{array}{l}\text { Next } \\
\text { quarter }\end{array}$ & Quarterly & $\begin{array}{l}\text { First } \\
\text { month }\end{array}$ & $\begin{array}{l}\text { Last } \\
\text { month }\end{array}$ & $\begin{array}{l}\text { Next } \\
\text { quarter }\end{array}$ \\
\hline Down & $\begin{array}{l}-1.26 \\
(-23.08)\end{array}$ & $\begin{array}{l}-0.43 \\
(-15.34)\end{array}$ & $\begin{array}{l}-0.69 \\
(-30.90)\end{array}$ & $\begin{array}{l}0.23 \\
(6.33)\end{array}$ & $\begin{array}{l}-1.56 \\
(-29.48)\end{array}$ & $\begin{array}{l}-0.32 \\
(-11.75)\end{array}$ & $\begin{array}{l}-0.94 \\
(-40.26)\end{array}$ & $\begin{array}{l}-0.21 \\
(-5.78)\end{array}$ & $\begin{array}{l}-1.64 \\
(-29.00)\end{array}$ & $\begin{array}{l}-0.52 \\
(-20.22)\end{array}$ & $\begin{array}{l}-0.50 \\
(-17.27)\end{array}$ & $\begin{array}{l}-0.10 \\
(-2.40)\end{array}$ \\
\hline Up & $\begin{array}{l}2.47 \\
(46.92)\end{array}$ & $\begin{array}{l}0.91 \\
(35.30)\end{array}$ & $\begin{array}{l}0.83 \\
(38.51)\end{array}$ & $\begin{array}{l}0.47 \\
(13.14)\end{array}$ & $\begin{array}{l}2.09 \\
(41.63)\end{array}$ & $\begin{array}{l}0.98 \\
(35.77)\end{array}$ & $\begin{array}{l}0.60 \\
(26.43)\end{array}$ & $\begin{array}{l}0.26 \\
(7.72)\end{array}$ & $\begin{array}{l}1.84 \\
(33.21)\end{array}$ & $\begin{array}{l}0.84 \\
(30.91)\end{array}$ & $\begin{array}{l}0.60 \\
(22.31)\end{array}$ & $\begin{array}{l}0.10 \\
(2.53)\end{array}$ \\
\hline Up minus down & $\begin{array}{l}3.59 \\
(46.23)\end{array}$ & $\begin{array}{l}0.94 \\
(30.57)\end{array}$ & $\begin{array}{l}1.09 \\
(43.36)\end{array}$ & $\begin{array}{l}0.24 \\
(5.87)\end{array}$ & $\begin{array}{l}3.52 \\
(45.78)\end{array}$ & $\begin{array}{l}0.94 \\
(30.13)\end{array}$ & $\begin{array}{l}1.11 \\
(41.47)\end{array}$ & $\begin{array}{l}0.47 \\
(11.17)\end{array}$ & $\begin{array}{l}3.36 \\
(41.08)\end{array}$ & $\begin{array}{l}0.97 \\
(31.94)\end{array}$ & $\begin{array}{l}0.80 \\
(27.12)\end{array}$ & $\begin{array}{l}0.24 \\
(5.18)\end{array}$ \\
\hline
\end{tabular}


Table 4 (continued)

Panel C: Mean quarterly abnormal returns of equally-weighted portfolios upgraded/downgraded by buy-side analysts when the sell-side consensus analyst recommendation simultaneously changes in the same direction (\%) (t-statistic)

\begin{tabular}{|c|c|c|c|c|c|c|c|c|c|c|c|}
\hline \multicolumn{4}{|c|}{ CAPM abnormal return } & \multicolumn{4}{|c|}{ Fama-French abnormal return } & \multicolumn{4}{|c|}{ Carhart abnormal return } \\
\hline Quarterly & $\begin{array}{l}\text { First } \\
\text { month }\end{array}$ & $\begin{array}{l}\text { Last } \\
\text { month }\end{array}$ & $\begin{array}{l}\text { Next } \\
\text { quarter }\end{array}$ & Quarterly & $\begin{array}{l}\text { First } \\
\text { month }\end{array}$ & $\begin{array}{l}\text { Last } \\
\text { month }\end{array}$ & $\begin{array}{l}\text { Next } \\
\text { quarter }\end{array}$ & Quarterly & $\begin{array}{l}\text { First } \\
\text { month }\end{array}$ & $\begin{array}{l}\text { Last } \\
\text { month }\end{array}$ & $\begin{array}{l}\text { Next } \\
\text { quarter }\end{array}$ \\
\hline
\end{tabular}

Mean quarterly abnormal returns of value-weighted portfolios upgraded/downgraded by buy-side analysts when the sell-side consensus analyst recommendation simultaneously changes in the same direction (\%) (t-statistic)

\begin{tabular}{|c|c|c|c|c|c|c|c|c|c|c|c|c|}
\hline & \multicolumn{4}{|c|}{ CAPM abnormal return } & \multicolumn{4}{|c|}{ Fama-French abnormal return } & \multicolumn{4}{|c|}{ Carhart abnormal return } \\
\hline & Quarterly & $\begin{array}{l}\text { First } \\
\text { month }\end{array}$ & $\begin{array}{l}\text { Last } \\
\text { month }\end{array}$ & $\begin{array}{l}\text { Next } \\
\text { quarter }\end{array}$ & Quarterly & $\begin{array}{l}\text { First } \\
\text { month }\end{array}$ & $\begin{array}{l}\text { Last } \\
\text { month }\end{array}$ & $\begin{array}{l}\text { Next } \\
\text { quarter }\end{array}$ & Quarterly & $\begin{array}{l}\text { First } \\
\text { month }\end{array}$ & $\begin{array}{l}\text { Last } \\
\text { month }\end{array}$ & $\begin{array}{l}\text { Next } \\
\text { quarter }\end{array}$ \\
\hline Down & $\begin{array}{l}-1.22 \\
(-24.82)\end{array}$ & $\begin{array}{l}-0.09 \\
(-3.75)\end{array}$ & $\begin{array}{l}-0.77 \\
(-35.19)\end{array}$ & $\begin{array}{l}0.08 \\
(2.18)\end{array}$ & $\begin{array}{l}-1.16 \\
(-23.69)\end{array}$ & $\begin{array}{l}-0.14 \\
(-5.19)\end{array}$ & $\begin{array}{l}-0.63 \\
(-27.30)\end{array}$ & $\begin{array}{l}-0.03 \\
(-0.91)\end{array}$ & $\begin{array}{l}-1.39 \\
(-25.90)\end{array}$ & $\begin{array}{l}-0.21 \\
(-8.22)\end{array}$ & $\begin{array}{l}-0.42 \\
(-14.17)\end{array}$ & $\begin{array}{l}0.23 \\
(5.63)\end{array}$ \\
\hline Up & $\begin{array}{l}1.46 \\
(32.90)\end{array}$ & $\begin{array}{l}0.59 \\
(24.60)\end{array}$ & $\begin{array}{l}0.58 \\
(29.22)\end{array}$ & $\begin{array}{l}-0.19 \\
(-5.50)\end{array}$ & $\begin{array}{l}1.34 \\
(30.20)\end{array}$ & $\begin{array}{l}0.57 \\
(22.60)\end{array}$ & $\begin{array}{l}0.70 \\
(31.95)\end{array}$ & $\begin{array}{l}-0.10 \\
(-2.97)\end{array}$ & $\begin{array}{l}1.22 \\
(24.60)\end{array}$ & $\begin{array}{l}0.55 \\
(21.99)\end{array}$ & $\begin{array}{l}0.75 \\
(28.27)\end{array}$ & $\begin{array}{l}-0.35 \\
(-9.19)\end{array}$ \\
\hline Up minus down & $\begin{array}{l}2.58 \\
(39.60)\end{array}$ & $\begin{array}{l}0.50 \\
(18.88)\end{array}$ & $\begin{array}{l}0.95 \\
(41.56)\end{array}$ & $\begin{array}{l}-0.23 \\
(-5.41)\end{array}$ & $\begin{array}{l}2.41 \\
(37.18)\end{array}$ & $\begin{array}{l}0.52 \\
(18.88)\end{array}$ & $\begin{array}{l}0.95 \\
(39.03)\end{array}$ & $\begin{array}{l}-0.03 \\
(-0.71)\end{array}$ & $\begin{array}{l}2.52 \\
(35.39)\end{array}$ & $\begin{array}{l}0.56 \\
(20.61)\end{array}$ & $\begin{array}{l}0.83 \\
(29.59)\end{array}$ & $\begin{array}{l}-0.50 \\
(-10.29)\end{array}$ \\
\hline
\end{tabular}

differences could be attributed to the characteristics of the stocks held by the institutions too. In this section of the analysis we examine a total of five variables: portfolio size, portfolio turnover, analyst coverage, analyst forecast dispersion, and the percentage of stock held by institutions. The last three variables are with respect to the attributes of the stocks held by the institutions.

Table 5 reports the time-series means of coefficients computed from quarterly regressions of buy-side institutions' abnormal returns of value-weighted portfolios formed by going long on upgraded and short on downgraded stocks. ${ }^{6}$ We calculate these abnormal returns using the Carhart (1997) four factor model that includes momentum in addition to the Fama-French three factor model and regress those returns on several variables in a multiple regression setting. We find that both portfolio size and portfolio turnover, where significant, relate positively to abnormal returns. Thus it appears that analysts in certain types of institutions (e.g. mutual funds, brokerage houses) who work with larger investment portfolios are more profitable than analysts in the same types of institutions who work with smaller portfolios. Additionally, within most types of institutions, analysts who more frequently change their recommendations are usually more profitable than those who do not.

Within most institution-types, including 'other' institutions, ${ }^{7}$ stocks covered by more analysts yield higher abnormal returns than do stocks covered by fewer analysts, and stocks with a low degree of dispersion in earnings forecasts outperform stocks with a high degree of dispersion. Within banks and brokerage firms, stocks that are to a larger extent held by institutions outperform stocks that are not. Looking across all institutions, most of these variables relate significantly to excess return. The intercept is significant and negative for the full sample and is the most negative and significant for the subsamples of brokerage firms, banks, and other institutions. This suggests (sample size differences notwithstanding) that the bulk of the institutional underperformance that we documented earlier is concentrated within these groups.

\section{Persistence}

It has been established that sell-side analysts not only generate profitable recommendations but also that the more successful analysts show persistence in their performance (see Mikhail, Walther, and

\footnotetext{
${ }^{6}$ We also computed results with equally-weighted portfolios and obtained similar findings. For the sake of brevity we do not report those results here.

7 The 'other' category includes university endowments, foundations, hedge funds, and other institutions that cannot be classified as banks, insurance firms, brokerage firms, or mutual funds.
}

Willis (2004), and Li (2005)). On the other hand, buy-side analysts' persistence is not very clear even though buy-side investment performance has been the subject of many studies. Most of the larger, more comprehensive studies find that buy-side trading yields negative or at best insignificant abnormal returns, while some recent studies using smaller datasets have found institutional investing to be profitable in at least some cases. Busse, Goyal, and Wahal (2010) find little evidence of persistence, particularly when they go beyond the three-factor model to calculate abnormal returns.

We examine the possibility of buy-side analyst persistence by first segmenting our sample of institutions that employ these analysts into deciles based on the most recent year's abnormal returns (calculated using the Carhart (1997) four factor model including momentum). ${ }^{8}$ The deciles are based on value-weighted ${ }^{9}$ zero-investment (longminus-short i.e. upgraded-minus-downgraded) portfolios of stocks for which the sell-side analysts' consensus recommendation simultaneously changed in the opposite direction. As we mentioned earlier, we focus on these stocks because they represent clear cases of disagreement with the sell-side and thus are the stocks most likely to have been traded based on the recommendations of their institutions' own (i.e. buyside) analysts.

We then look ahead to see what each decile's four-factor abnormal return is over alternately the next quarter, the next year, and the next two years. ${ }^{10}$ We report the time-series means of the subsequent quarterly, one-year-ahead and two-year-ahead returns in Table 6. The first column in the table shows that there is considerable disparity between our groups; excess returns over the past year range from an average of $-0.625 \%$ for the lowest decile to $0.16 \%$ for the top decile. Additionally, there is ample evidence of persistence. Whether we measure excess returns one quarter, one year, or two years ahead, they increase monotonically with the pre-period performance decile. Additionally, the difference between the bottom and top deciles ("D10 minus D1") is everywhere negative and highly significant. Given that the excess returns shown in Table 6 are based on the Carhart (1997) model, we can say that we find strong evidence of persistence, both overall and cross-sectionally, for buy-side analysts and that this persistence extends

\footnotetext{
${ }^{8}$ We concentrate on this benchmark owing to the importance of momentum in return persistence.

${ }^{9}$ For robustness we used equally-weighted portfolios and found similar results. For brevity we do not report them here.

${ }^{10}$ The abnormal return is calculated by regressing the excess returns of equallyweighted portfolios of upgraded minus downgraded stocks on the four factors in Carhart (1997) as shown in Section 2.3. The intercept plus the residual in each quarter equals the abnormal return for that quarter. The quarterly return is compounded from monthly returns.
} 
Table 5

Regressions of buy-side recommendation changes-based long-short portfolio's quarterly.

Abnormal returns on portfolio and stock characteristics.

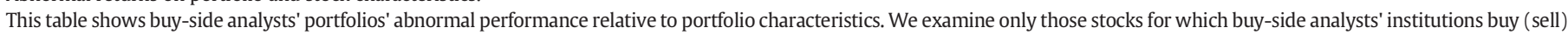

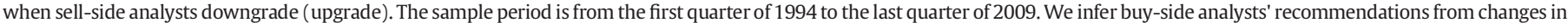

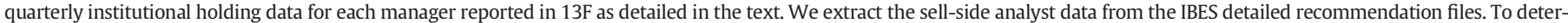

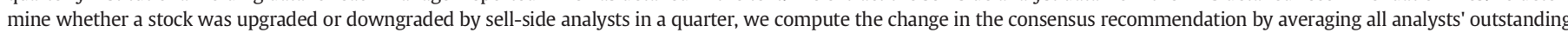

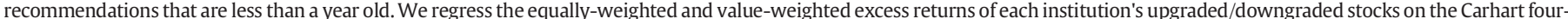

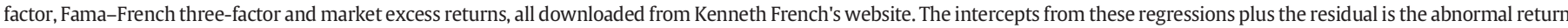

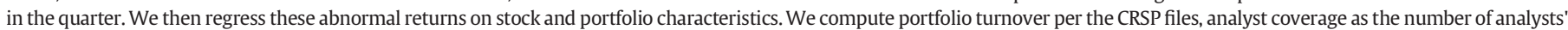

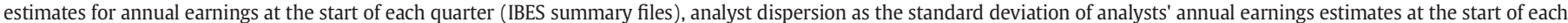

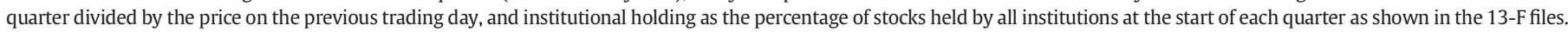
The figures reported below are the time-series means of quarterly cross-sectional regressions.

\begin{tabular}{|c|c|c|c|c|c|c|}
\hline Variables & All institutions & Banks & Insurance firms & Mutual funds & Brokerage firms & Others \\
\hline Intercept & $-17.776^{* * *}$ & $-8.170^{* * *}$ & -3.517 & -4.746 & $-18.032^{* * *}$ & $-14.430^{* * *}$ \\
\hline Portfolio size & $3.107-\mathrm{E} 11^{* * * *}$ & $4.485-\mathrm{E} 11^{* * *}$ & $-7.439-\mathrm{E} 11$ & $1.340-\mathrm{E} 11^{* * *}$ & 3.716-E $11^{* * *}$ & 7.630-E11 ${ }^{* * *}$ \\
\hline Portfolio turnover & $0.004^{* * *}$ & -0.001 & $0.023^{* * *}$ & $0.019^{* * *}$ & $0.008^{* * *}$ & -0.002 \\
\hline Analyst Coverage & $0.347^{* * *}$ & $0.107^{* *}$ & $0.102^{*}$ & 0.013 & $0.326^{* * *}$ & $0.443^{* * *}$ \\
\hline Analyst dispersion & $-11.131^{* * *}$ & -162.517 & $-64.835^{* * *}$ & $-45.803^{* * *}$ & $-17.821^{* *}$ & $-29.440^{* * * *}$ \\
\hline Institutional Holding & $0.106^{* * *}$ & $0.058^{* *}$ & -0.051 & -0.012 & $0.113^{* * *}$ & 0.018 \\
\hline Average number of obs. quarter & 1519 & 142 & 54 & 67 & 909 & 305 \\
\hline
\end{tabular}

\section{Table 6}

Persistence of buy-side analyst profitability.

This table shows buy-side analysts' persistence in profitability. We examine only those stocks for which both buy-side and sell-side analysts provide coverage and hold divergent opinions in a quarter i.e. buy-side analysts' institutions buy (sell) when sell-side analysts downgrade (upgrade) the stock. The sample period is from the first quarter of 1994 to the last quarter of 2009. We infer buy-side analysts' recommendations from the changes in quarterly institutional holding data for each manager reported in $13 \mathrm{~F}$ as detailed in the text. We extract sell-side analyst data from the IBES detailed recommendation files. To determine whether a stock was upgraded or downgraded by sell-side analysts in a quarter, we compute the change in the consensus recommendation at the end of each quarter by averaging all analysts' outstanding recommendations that are less than one year old. We obtain quarterly excess returns by regressing the equally-weighted and value-weighted excess returns of each institution's upgraded/downgraded stocks on the Carhart four-factor returns downloaded from Kenneth French's website. The intercepts from these regressions plus the residual are the abnormal returns in the quarter. Yearly abnormal returns are monthly abnormal returns compounded. We sort buy-side analysts into 10 groups based on the past year's abnormal returns. We report the time-series means of the subsequent quarterly, one-year, and two-year returns.

\begin{tabular}{|c|c|c|c|c|}
\hline \multicolumn{5}{|c|}{$\begin{array}{l}\text { Abnormal future returns for equally-weighted portfolio deciles based on abnormal } \\
\text { past returns }\end{array}$} \\
\hline Decile & $\begin{array}{l}\text { Past year } \\
\text { abnormal } \\
\text { return } \\
\text { (t-statistic) }\end{array}$ & $\begin{array}{l}\text { Next quarter } \\
\text { abnormal } \\
\text { return } \\
\text { (t-statistic) }\end{array}$ & $\begin{array}{l}\text { Next year } \\
\text { abnormal } \\
\text { return } \\
\text { (t-statistic) }\end{array}$ & $\begin{array}{l}\text { Next } 2 \text { years } \\
\text { abnormal } \\
\text { return } \\
\text { (t-statistic) }\end{array}$ \\
\hline $\begin{array}{l}\text { D1 } \\
\text { (Least profitable) }\end{array}$ & $\begin{array}{l}-0.6247 \\
(-37.29)\end{array}$ & $\begin{array}{l}-0.1205 \\
(-16.39)\end{array}$ & $\begin{array}{l}-0.3799 \\
(-27.12)\end{array}$ & $\begin{array}{l}-0.5653 \\
(-36.21)\end{array}$ \\
\hline D2 & $\begin{array}{l}-0.4303 \\
(-32.24)\end{array}$ & $\begin{array}{l}-0.0948 \\
(-18.79)\end{array}$ & $\begin{array}{l}-0.3185 \\
(-25.78)\end{array}$ & $\begin{array}{l}-0.5072 \\
(-31.79)\end{array}$ \\
\hline D3 & $\begin{array}{l}-0.3442 \\
(-29.38)\end{array}$ & $\begin{array}{l}-0.0816 \\
(-18.60)\end{array}$ & $\begin{array}{l}-0.2776 \\
(-25.45)\end{array}$ & $\begin{array}{l}-0.4587 \\
(-31.40)\end{array}$ \\
\hline D4 & $\begin{array}{l}-0.2848 \\
(-26.93)\end{array}$ & $\begin{array}{l}-0.0734 \\
(-17.12)\end{array}$ & $\begin{array}{l}-0.2519 \\
(-24.88)\end{array}$ & $\begin{array}{l}-0.4211 \\
(-29.68)\end{array}$ \\
\hline D5 & $\begin{array}{l}-0.2373 \\
(-24.79)\end{array}$ & $\begin{array}{l}-0.0659 \\
(-15.87)\end{array}$ & $\begin{array}{l}-0.2248 \\
(-22.54)\end{array}$ & $\begin{array}{l}-0.3882 \\
(-26.34)\end{array}$ \\
\hline D6 & $\begin{array}{l}-0.1941 \\
(-22.33)\end{array}$ & $\begin{array}{l}-0.0583 \\
(-16.34)\end{array}$ & $\begin{array}{l}-0.2067 \\
(-23.04)\end{array}$ & $\begin{array}{l}-0.3611 \\
(-26.44)\end{array}$ \\
\hline D7 & $\begin{array}{l}-0.1499 \\
(-19.34)\end{array}$ & $\begin{array}{l}-0.0527 \\
(-15.14)\end{array}$ & $\begin{array}{l}-0.1898 \\
(-20.74)\end{array}$ & $\begin{array}{l}-0.3325 \\
(-24.29)\end{array}$ \\
\hline D8 & $\begin{array}{l}-0.0991 \\
(-14.79)\end{array}$ & $\begin{array}{l}-0.0470 \\
(-12.23)\end{array}$ & $\begin{array}{l}-0.1659 \\
(-18.91)\end{array}$ & $\begin{array}{l}-0.2955 \\
(-22.07)\end{array}$ \\
\hline D9 & $\begin{array}{l}-0.0309 \\
(-6.13)\end{array}$ & $\begin{array}{l}-0.0411 \\
(-8.98)\end{array}$ & $\begin{array}{l}-0.1393 \\
(-15.57)\end{array}$ & $\begin{array}{l}-0.2503 \\
(-17.81)\end{array}$ \\
\hline $\begin{array}{l}\text { D10 } \\
\text { (Most profitable) }\end{array}$ & $\begin{array}{l}0.1605 \\
(24.84)\end{array}$ & $\begin{array}{l}-0.0268 \\
(-4.37)\end{array}$ & $\begin{array}{l}-0.0834 \\
(-6.46)\end{array}$ & $\begin{array}{l}-0.1404 \\
(-7.17)\end{array}$ \\
\hline D10 minus D1 & $\begin{array}{l}-0.7852 \\
(-43.73)\end{array}$ & $\begin{array}{l}-0.0937 \\
(-9.79)\end{array}$ & $\begin{array}{l}-0.2965 \\
(-15.57)\end{array}$ & $\begin{array}{l}-0.4249 \\
(-16.97)\end{array}$ \\
\hline
\end{tabular}

******, denote statistical significance better than $1 \%, 5 \%$, and $10 \%$ using two-tailed t-statistics respectively. beyond momentum. Thus overall our results imply that even though a typical buy-side analyst does not increase their institutions' returns, there nevertheless is cross-sectional variation across analysts in terms of the type of institution they work for and the persistence of their performance.

\section{Conclusions}

To date, the literature on buy-side analyst performance, especially as it relates to sell-side analyst performance, is mixed. Most of the comprehensive studies of mutual funds find either negative or statistically insignificant abnormal returns. Several recent studies of buy-side analysts who work for mutual funds, however, find positive abnormal returns containing value incremental to that which is provided by sellside recommendations. This discrepancy could owe to the different datasets used in these studies (many of the more recent studies use limited samples of proprietary data), the inherent differences between mutual funds and other institutions, or other factors.

This study attempts to help fill in these gaps by examining a more comprehensive dataset of both institutional and analyst activities to determine the simultaneous behavior of buy-side and sell-side analysts and the performance of the portfolios based on their recommendations. We also examine the potential effect of portfolio characteristics on contemporaneous excess returns as well as the persistence in buy-side performance.

We report the following results. First, portfolios formed on the basis of analyst recommendations have negative contemporaneous excess returns for the buy-side and positive contemporaneous excess returns for the sell-side. Second, when we examine and compare three categories of recommendations of buy-side analysts: (1) when sell-side analysts concurrently change recommendations in accordance with the institutional trade, (2) when sell-side analysts do not change recommendations, and (3) when sell-side analysts give recommendations opposite to buy-side analysts' recommendations, we find that only when institutions go along with sell-side analysts' recommendations do they increase the abnormal returns to their portfolios, and that institutional returns are lowest when they go against sell-side recommendations. The returns are for the most part evenly distributed throughout the three months of the quarter, suggesting that on balance institutional trading is unprofitable, and the results do not materially change when we examine the following quarter in addition to the quarter in which the trade took place. Third, buy-side analysts working for large 
institutions tend to perform better and are associated with greater portfolio turnover, presumably because they take advantage of short-term information as documented in the institutional literature. Fourth, even though buy-side analysts on average do not generate positive excess returns, they nevertheless show persistence in performance over the next one to two years. Overall, this study offers more comprehensive evidence on the relative contribution of buy-side and sell-side analysts to the performance of institutions as a whole.

\section{References}

Altinkilic, O., Balashov, V., \& Hansen, R. (2013). Are analysts' forecasts informative to the general public? Management Science, 59, 2550-2565.

Altinkilic, O., \& Hansen, R. (2009). On the information role of stock recommendation revisions. Journal of Accounting and Economics, 48, 17-36.

Avramov, D., \& Wermers, R. (2006). Investing in mutual funds when returns are predictable. Journal of Financial Economics, 81, 339-377.

Barber, B., Lehavy, R., McNichols, M., \& Trueman, B. (2001). Can investors profit from the prophets? Security analyst recommendations and stock returns. Journal of Finance, 56, 531-563.

Barber, B., Lehavy, R., McNichols, M., \& Trueman, B. (2003). Reassessing the returns to analysts' stock recommendations. Financial Analysts Journal, 59, 88-96.

Barber, B., Lehavy, R., \& Trueman, B. (2007). Comparing the stock recommendation performance of investment banks and independent research firms. Journal of Financial Economics, 85, 490-517.

Barber, B., Odean, T., \& Zhang, L. (2005). Out of sight, out of mind: The effects of expenses on mutual fund flows. Journal of Business, 78, 2095-2119.

Barras, L., Scaillet, O., \& Wermers, R. (2009). False discoveries in mutual fund performance: Measuring luck in estimated alphas. Journal of Finance, 65, 179-216.

Berk, J., \& Xu, J. (2007). Persistence and fund flows of the worst performing mutual funds. NBER working paper no. w13042.

Binay, M. (2005). Performance attribution of U.S. institutional investors. Financial Management, 34, 127-152.

Bollen, N., \& Busse, J. (2005). Short-term persistence in mutual fund performance. Review of Financial Studies, 18, 569-597.

Brown, K.C., Harlow, W.V., \& Starks, L.T. (1996). Of tournaments and temptations: An analysis of managerial incentives in the mutual fund industry. The Journal of Finance, 51, 85-110.

Busse, J., Green, C., \& Jegadeesh, N. (2012). Buy-side trades and sell-side recommendations: Interactions and information content. Journal of Financial Markets, 15, 207-232.

Busse, J., Goyal, A., \& Wahal, S. (2010). Performance persistence in institutional investment management. Journal of Finance, 65, 765-790.

Carhart, M. (1997). On persistence in mutual fund performance. Journal of Finance, 52, $57-82$.

Chen, H., Jegadeesh, N., \& Wermers, R. (2000). The value of active mutual fund management: An examination of the stockholdings and trades of fund managers. Journal of Financial and Quantitative Analysis, 35, 343-368.

Cheng, Y., Liu, M., \& Qian, J. (2006). Buy-side analysts, sell-side analysts, and investment decisions of money managers. Journal of Financial and Quantitative Analysis, 41. $51-83$.

Chevalier, J., \& Ellison, G. (1997). Risk taking by mutual funds as a response to incentives. Journal of Political Economy, 105, 1167-1200.

Chevalier, J., \& Ellison, G. (1999). Career concerns of mutual fund managers. Quarterly Journal of Economics, 114, 389-432.

Cohen, R., Coval, J., \& Pastor, L. (2005). Judging fund managers by the company they keep. Journal of Finance, 60, 1057-1096.

Conrad, J., Cornell, B., Landsman, W., \& Rountree, B. (2006). How do analyst recommendations respond to major news? Journal of Financial and Quantitative Analysis, 41, 25-48.

Crawford, S., Gray, W., Johnson, B., \& Price, R. (2012). Do buy-side recommendations have investment value? Working paper.

Dimson, E., \& Marsh, P. (1984). An analysis of brokers' and analysts' unpublished forecasts of U.K. stock returns. Journal of Finance, 39, 1257-1292.

Elton, E., Gruber, M., \& Grossman, S. (1986). Discrete expectational data and portfolio performance. Journal of Finance, 41, 699-714.
Ertimur, Y., Sunder, J., \& Sunder, S. (2007). Measure for measure: The relation between forecast accuracy and recommendation profitability of analysts. Journal of Accounting Research, 45, 567-606.

Fama, E., \& French, K. (1993). Common risk factors in the returns on stocks and bonds. Journal of Financial Economics, 33, 3-56.

Fama, E., \& French, K. (2008). Mutual fund performance. Working paper.

Fang, L., \& Yasuda, A. (2009). Are stars' opinions worth more? The relation between analyst reputation and recommendation values. SSRN working paper.

Frey, S., \& Herbst, P. (2014). The influence of buy-side analysts on mutual fund trading. Journal of Banking \& Finance, 49, 442-458.

Griffin, J., Harris, J., Shu, T., \& Topaloglu, S. (2011). Who drove and burst the tech bubble? Journal of Finance, 66, 1251-1290.

Grinblatt, M., Titman, S., \& Wermers, R. (1995). Momentum investment strategies, portfolio performance, and herding: A study of mutual fund behavior. American Economic Review, 85, 1088-1105.

Groysberg, B., Healy, P., Serafeim, G., Shanthikumar, D., \& Gui, Y. (2010). The performance of buy-side analyst recommendations. SSRN working paper.

Hobbs, J., Kovacs, T., \& Sharma, V. (2012). The investment value of the frequency of analyst recommendation changes for the ordinary investor. Journal of Empirical Finance, 19, 94-108

Howe, J., Unlu, E., \& Yan, X. (2009). The predictive content of aggregate analyst recommendations. Journal of Accounting Research, 47, 799-821.

Jegadeesh, N., \& Kim, W. (2006). Value of analyst recommendations: International evidence. Journal of Financial Markets, 9, 274-309.

Jegadeesh, N., Kim, J., Krische, S., \& Lee, C. (2004). Analyzing the analysts: When do recommendations add value? Journal of Finance, 59, 1083-1124.

Jensen, M. (1968). The performance of mutual funds in the period 1945-1964. Journal of Finance, 48, 389-416.

Kacperczyk, M., \& Seru, A. (2007). Fund manager use of public information: New evidence on managerial skills. Journal of Finance, 62, 485-528.

Kempf, A., Ruenzi, S., \& Thiele, T. (2009). Employment risk, compensation incentives, and managerial risk taking: Evidence from the mutual fund industry. Journal of Financial Economics, 92, 92-108.

Kosowski, R., Timmermann, A., Wermers, R., \& White, H. (2006). Can mutual fund "stars" really pick stocks? New evidence from a bootstrap analysis. Journal of Finance, 61, 2551-2595.

Lakonishok, J., Shleifer, A., \& Vishny, R. (1992). The structure and performance of the money management industry. Brookings Papers Microeconomics, 339-391.

$\mathrm{Li}, \mathrm{X}$. (2005). The persistence of relative performance in stock recommendations of sellside financial analysts. Journal of Accounting and Economics, 40, 129-152.

Lin, H., \& McNichols, M. (1998). Underwriting relationships, analysts' earnings forecasts and investment recommendations. Journal of Accounting and Economics, 25, 101-127.

Logue, D., \& Tuttle, D. (1973). Brokerage house investment advice. Financial Review, 8 , $38-54$.

Loh, R., \& Mian, M. (2006). Do accurate earnings forecasts facilitate superior investment recommendations? Journal of Financial Economics, 80, 455-483.

Loh, R., \& Stulz, R. (2011). When are analyst recommendation changes influential? Review of Financial Studies, 24, 593-627.

Malmendier, U., \& Shanthikumar, D. (2014). Do security analysts speak in two tongues? Review of Financial Studies, 27, 1287-1322.

Mikhail, M., Walther, B., \& Willis, R. (2004). Do security analysts exhibit persistence differences in stock picking ability? Journal of Financial Economics, 74, 67-91.

Michaely, R., \& Womack, K. (1999). Conflict of interest and the credibility of underwriter analyst recommendations. Review of Financial Studies, 12, 653-686.

Nofsinger, J., \& Sias, R. (1999). Herding and feedback trading by institutional and individual investors. Journal of Finance, 54, 2263-2295.

Olivier, J., \& Tay, A. (2009). Time-varying incentives in the mutual fund industry. HEC Paris and Singapore Management University.

Pagani, M., Hu, P., Kale, J., \& Subramanian, A. (2011). Fund flows, performance, managerial concerns, and risk-taking. Management Science, 57, 628-646.

Sias, R. (2007). Window-dressing, tax-loss selling and momentum profit seasonality. Financial Analyst Journal, 63, 48-54.

Wermers, R. (1999). Mutual fund herding and the impact on stock prices. Journal of Finance, 54, 581-622.

Womack, K. (1996). Do brokerage analysts' recommendations have investment value? Journal of Finance, 51, 137-167. 